\title{
The Tricarboxylic Acid Cycle at the Crossroad Between Cancer and Immunity
}

\author{
Alessandra Scagliola, ${ }^{*}$ Francesco Mainini, ${ }^{*}$ and Simone Cardaci
}

\begin{abstract}
Significance: The tricarboxylic acid (TCA) cycle is a housekeeping metabolic pathway essential for generation of energy and biosynthetic intermediates. Alterations of the TCA cycle play a pivotal role in oncogenesis and inflammation. As such, some metabolic vulnerabilities, imposed by TCA cycle dysfunction in cancer, have been identified. Similarly, the TCA cycle appeared as an actionable pathway in immunopathologies.

Recent Advances: Metabolic changes accompanying cell transformation have been usually considered as adaptive mechanisms to malignant transformation. The identification of oncogenic mutations in some TCA cycle enzymes changed this view, indicating altered mitochondrial metabolism as an instrumental mechanism for cancer initiation. Similarly, the observation that TCA cycle-derived metabolites have multiple signaling roles in immune cells supports the idea of this pathway as a metabolic rheostat of immune responses.

Critical Issues: This review summarizes the crucial role of the TCA cycle in pathophysiology describing the posttranslational and epigenetic impact of oncometabolites accumulation in cancer and immune cells.

Future Directions: Additional studies will be necessary to further explore the role of oncometabolites in paracrine signaling and to identify genuine metabolic and nutritional liabilities imposed by TCA cycle dysfunction in cancer, hardly to be escaped by resistance mechanisms. Antioxid. Redox Signal. 32, 834-852.
\end{abstract}

Keywords: metabolism, cancer, inflammation, oncometabolites, metabolic vulnerabilities

\section{Introduction}

$\mathbf{M}$ ETABOLISM CONSISTS OF a series of coordinated and integrated enzyme-catalyzed biochemical reactions aimed at converting nutrients into energy and biomolecules enabling survival, growth, and differentiation of normal cells. Such metabolic pathways are dramatically rewired during tumorigenesis, to meet biomass, energy, and redox demands imposed by uncontrolled cancer cell proliferation, even in nutrient stress conditions (40). Likewise malignant cells, both innate and adaptive immune cells, acquire specific bioenergetic features sustaining their activation, elicited by infections and inflammatory stimulations (81).

Although metabolic reprogramming has been thought for decades as a mere adaptation to any conditions altering cell fitness, acquisition of growing knowledge demonstrates that it plays instrumental roles in driving malignant transformation, as well as dictating cell fate and effector functions in immunity. In this context, of particular interest is the tricarboxylic acid (TCA) cycle, a housekeeping metabolic pathway responsible for generation of redox cofactors, enabling mitochondrial ATP biosynthesis, and anabolic intermediates. Mutations altering the functions of three TCA cycle enzymes, succinate dehydrogenase $(\mathrm{SDH})$, fumarate hydratase $(\mathrm{FH})$, and isocitrate dehydrogenase (IDH), have been associated with specific forms of cancer, suggesting a causal role for the TCA cycle in tumor formation $(18,101,111)$. Similarly, coordinated changes in the levels of some TCA cycle-derived metabolites having signaling roles, such as succinate and itaconate, are known to regulate both the type and the extent of immune responses, thus pointing toward a role for the TCA cycle as a metabolic controller of immune cells' functions $(79,95)$.

Cancer Metabolism Unit, Division of Genetics and Cell Biology, IRCCS San Raffaele Scientific Institute, Milan, Italy.

*These authors contributed equally to this work and are co-first authors. 
Therefore, this review summarizes the oncogenic and immunoregulatory mechanisms driven by alterations of the TCA cycle, describing the transcriptional, epigenetic, and post-translational impact of its oncometabolites on the regulation of gene expression and signal transduction. Moreover, promising therapeutic opportunities created by TCA cycle dysfunctions will be reviewed, providing insights on the metabolic vulnerabilities imposed by mutations in TCA cycle genes in cancer, as well as discussing the therapeutic value of targeting this metabolic pathway in immunopathologies.

\section{Fundamentals of the TCA Cycle}

The TCA cycle, also known as the citric acid or Krebs cycle, is a core metabolic pathway, taking place mainly in the mitochondrial matrix, aimed at producing reducing equivalents (nicotinamide adenine dinucleotide (reduced form) [NADH] and flavin adenine dinucleotide (hydroquinone form) $\left[\mathrm{FADH}_{2}\right]$ ), oxidized by the mitochondrial electron transfer chain (ETC), for ATP biosynthesis (Fig. 1). It is considered an amphibolic pathway since it acts both as an end point for catabolism of sugars, lipids, and amino acids and a source of intermediates for synthesis of cellular building blocks.

It begins with the condensation of a two carbon-moiety provided by acetyl-coenzyme A with oxaloacetate to form citrate, in a reaction catalyzed by citrate synthase (CS) in the mitochondrial matrix. Citrate can be exported to the cytoplasm, where it is used as a precursor for lipids biosynthesis, or remain in the mitochondria, where is converted into isocitrate by aconitase, via cis-aconitate formation. In the third step, IDH couples the stoichiometric oxidative decarboxylation of isocitrate to $\alpha$-ketoglutarate $(\alpha-\mathrm{KG})$ with the generation of $\mathrm{NADH}$. Importantly, such reaction can proceed toward the opposite direction through the reductive carboxylation of $\alpha-\mathrm{KG}$, catalyzed by NADPH-dependent IDH isoforms. This allows cells to produce citrate to support de novo lipogenesis and cell viability under hypoxia or conditions impairing the mitochondrial ETC functionality $(72,77)$. In normal conditions, the TCA cycle proceeds oxidatively toward the further decarboxylation of $\alpha-K G$ to succinyl-CoA by the $\alpha-K G$ dehydrogenase complex, in a reaction producing an additional NADH molecule. Succinyl-CoA is then hydrolyzed to succinate by the succinylCoA synthetase, by a substrate-level phosphorylation reaction producing either GTP or ATP. Alternatively, succinyl-CoA carbons can escape from the cycle, to be used as substrate, together with glycine, for the formation of D-aminolevulinic acid, the first precursor in heme biosynthesis. Succinate can also be formed via a sequence of three reactions involving synthesis and degradation of $\gamma$-aminobutyric acid (GABA), collectively known as the GABA shunt. The next step, the oxidation of succinate to fumarate, coupled to generation of $\mathrm{FADH}_{2}$, is catalyzed by SDH, also known as succinate:ubiquinone oxidoreductase or complex II of the mitochondrial ETC. In the seventh step, fumarate is hydrated to malate by FH

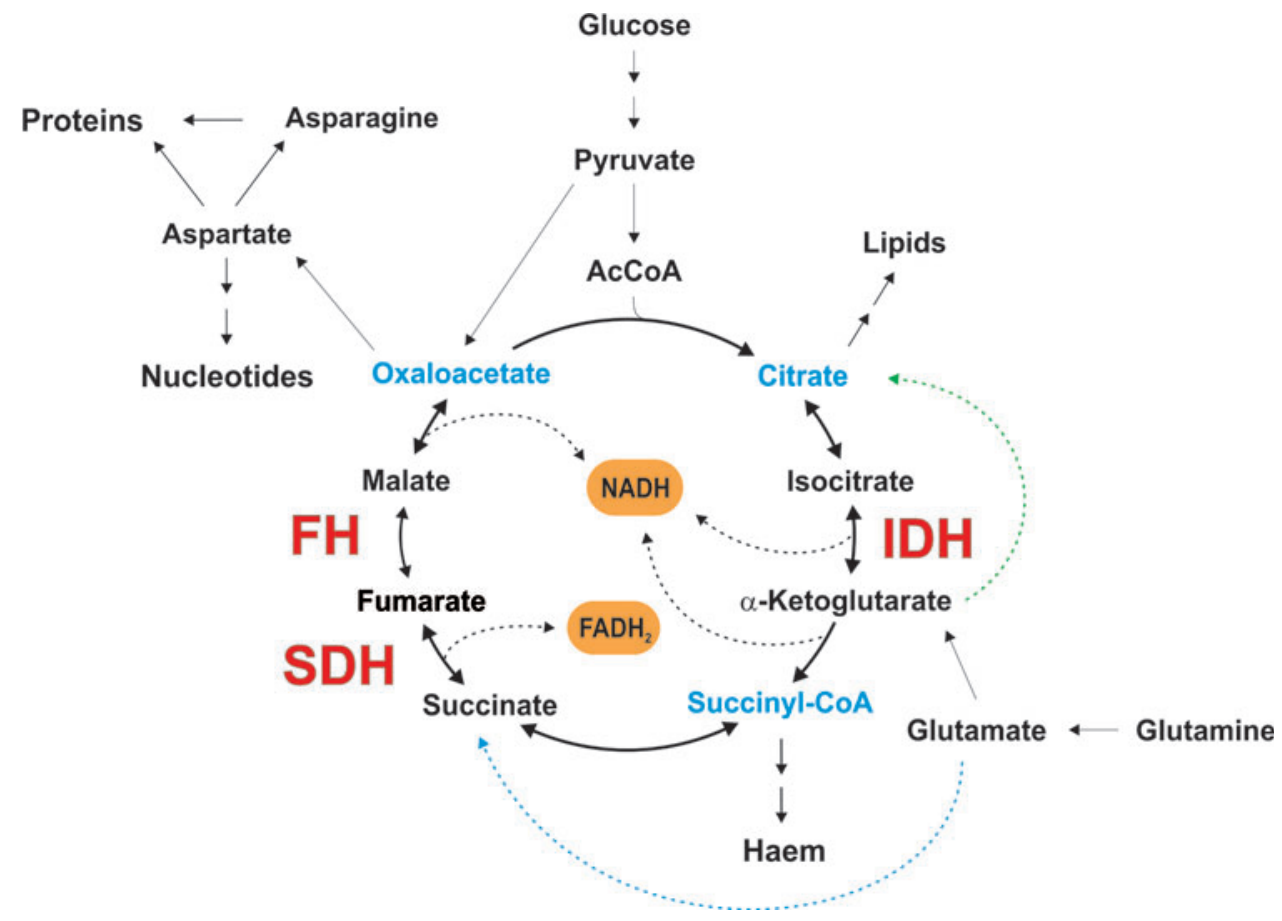

FIG. 1. Overview of the TCA cycle. The TCA cycle is the core metabolic route for the production of reducing equivalents (NADH and $\mathrm{FADH}_{2}$ ) utilized by the mitochondrial respiratory chain for ATP synthesis. Carbons are mainly supplied to the TCA cycle through catabolism of glucose and glutamine. Some TCA cycle metabolites (in blue) are important biosynthetic precursors, such as citrate, oxaloacetate, and succinyl-coenzyme A, required for the production of lipids, aspartate, and heme, respectively. Enzymes mutated in cancer are in red. Bold black arrows indicate TCA cycle reactions. Black dotted arrows show reactions producing $\mathrm{NADH}$ and $\mathrm{FADH}_{2}$. Green dotted arrow indicates reductive carboxylation of glutamine. Blue dotted arrow indicates synthesis of succinate via the GABA shunt. AcCoA, acetylcoenzyme A; $\mathrm{FADH}_{2}$, flavin adenine dinucleotide (hydroquinone form); $\mathrm{FH}$, fumarate hydratase; GABA, $\gamma$-aminobutyric acid; IDH, isocitrate dehydrogenase; NADH, nicotinamide adenine dinucleotide (reduced form); SDH, succinate dehydrogenase; TCA, tricarboxylic acid. Color images are available online. 
enzyme. Finally, malate oxidation, catalyzed by malate dehydrogenase, generates a third NADH molecule and oxaloacetate. The latter can provide carbon skeleton for transamination of glutamate to aspartate or be re-used by CS, thus completing the cycle (18).

\section{TCA Cycle Defects in Cancer}

Metabolic reprogramming has long been considered a hallmark of cancer; however, such biochemical changes have been usually considered as adaptive mechanisms to cellular transformation. This viewpoint changed when mutations in three genes encoding for TCA cycle enzymes, SDH, FH, and IDH, were associated with human malignant transformation. Since then, a number of potential tumorigenic mechanisms elicited by the accumulation of three TCA cycle-associated metabolites, succinate, fumarate, and 2-hydroxyglutarate (2-HG), have been reported, supporting the view of the TCA cycle as a metabolic platform regulating oncogenic signaling.

\section{Succinate dehydrogenase}

$\mathrm{SDH}$ is the enzymatic complex responsible of the oxidation of succinate to fumarate in the TCA cycle with the simultaneously reduction of ubiquinone to ubiquinol in the mitochondrial ETC. It is composed of four subunits, SDHA, SDHB, SDHC, and SDHD, anchored to the inner mitochondrial membrane and assembled together by two assembly factors SDHAF1 and SDHAF2, all encoded by the nuclear genome (118). It is considered as a bona fide tumor suppressor protein complex, as heterozygous germline loss-of-function mutations in any human $S D H$ genes predispose to familial cancer syndromes (Fig. 2). Mutations in $S D H B, S D H C$, and $S D H D$ genes were originally identified in patients with hereditary pheochromocytomas (PHEO) and paragangliomas (PGG), rare neuroendocrine neoplasms of the chromaffin tissue of the adrenal medulla, or arising from the parasympathetic tissue of the head and neck paraganglia, respectively $(5,12,13,78,80)$. Later, mutations in $S D H A$ and in $S D H A F 2$ were associated with PGG/PHEO syndrome as well $(10,39$, $60)$. In addition, $S D H B$ was found mutated in renal carcinomas $(92,117)$, and mutations in several $S D H$ genes have been associated with gastrointestinal stromal cancer, T cell leukemia, thyroid tumors, testicular seminoma, neuroblastomas, and pituitary tumors $(9,11)$.

In the above-described SDH-associated cancer syndromes, the neoplastic transformation derives from the combination of two genetic hits: (i) an inactivating germline mutation and (ii) the subsequent loss of heterozygosity, caused by the mutation (usually deletion) of the second allele in tumor cells, resulting in a complete deficiency of the enzyme activity and abnormal accumulation of succinate in the tumor $(36,87)$.

Although genetics associates mutational inactivation of SDH with human cancer syndromes, the mechanistic link between succinate and malignant transformation has not been fully demonstrated yet. However, some observations suggested a causal role for succinate accumulation in tumorigenic processes. The first clue was based on the detection of strong hypoxic features in SDH-associated tumors (35). This evidence allowed to hypothesize an instrumental role for the hypoxia-inducible factor 1 (HIF-1) in the pathogenesis of such malignancies. The second hint derived from work performed in Gottlieb laboratory who demonstrated that accumulation of succinate in SDH-null cells results in HIF- $1 \alpha$ stabilization (104). Specifically, HIF-1 is a transcription factor eliciting an established protumorigenic effect promoting cancer cell survival, proliferation, and angiogenesis. It is composed of two subunits: an oxygen-sensitive $\alpha$ subunit and a constitutively active $\beta$ partner. In the presence of oxygen, two proline residues (Pro ${ }^{402}$ and Pro ${ }^{564}$ ) in HIF- $\alpha$ subunit are hydroxylated by prolyl-hydroxylases (PHDs), members of

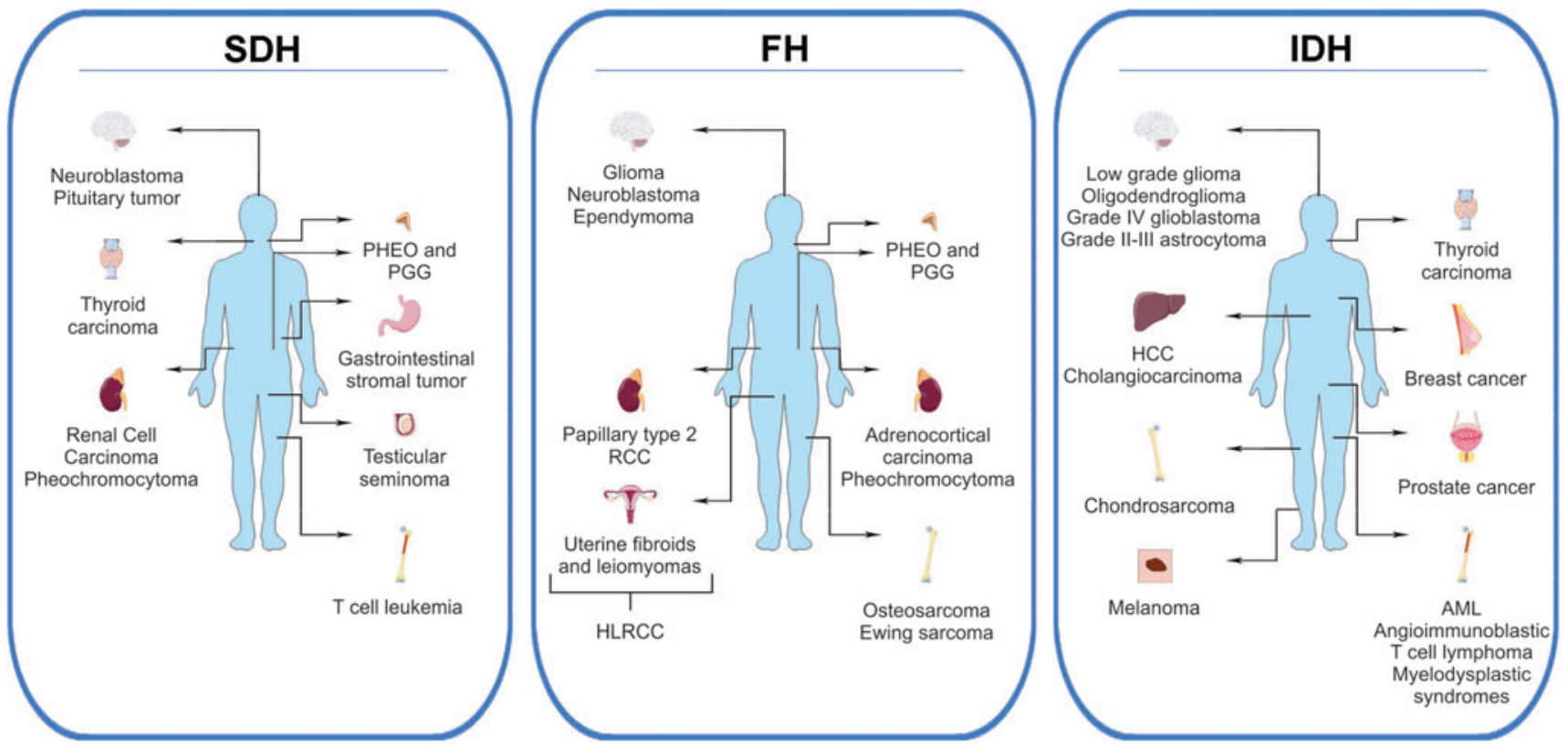

FIG. 2. TCA cycle and cancer. Representation of the various tissues affected by hereditary or sporadic mutations in genes encoding for SDH, FH, and IDH enzymes. PHEO and PGG, pheochromocytomas and paragangliomas; AML, acute myeloid leukemia; HCC, hepatocellular carcinoma; HLRCC, hereditary leiomyomatosis and renal cell cancer syndrome; RCC, renal cell carcinoma. Color images are available online. 
the $\alpha$-KG-dependent dioxygenases ( $\alpha$ KGDDs) family of enzymes, which couple the hydroxylation of the substrates with the oxidation of $\alpha-\mathrm{KG}$ to succinate, in an oxygen and $\mathrm{Fe}^{2+}$ and ascorbate-dependent reaction (Fig. 3) (82). Then, the hydroxylated HIF-1 $\alpha$ subunits are recognized and polyubiquitinated by ubiquitin ligases, priming the transcription factor for a proteasome-dependent degradation (100). Under limited oxygen tension, the degradation of HIF- $1 \alpha$ is prevented enabling its dimerization with HIF-1 $\beta$ subunit in the nucleus and binding to the hypoxia response elements (HRE) in the promoters of its target genes, thus driving a hypoxic response. This involves the transcription of genes implicated in induction of angiogenesis, such as the vascular endothelial growth factor as well as glycolysis, including the glucose transporter 1 (GLUT1) and lactate dehydrogenase A.

Similar to hypoxia, succinate accumulation in SDHdeficient cells inhibits PHDs via a product-inhibition mechanism, thus stabilizing HIF- $1 \alpha$ in normoxic (pseudohypoxic) conditions (Fig. 4) (104). Interestingly, succinate might also stabilize HIF- $1 \alpha$ in cancer cells devoid of mutations in $S D H$ genes. Indeed, the tumor necrosis factor-associated protein 1 (TRAP1), a mitochondrial chaperone highly expressed in several tumors (90), was demonstrated to bind the SDH complex and inhibit its activity. This results in the accumulation of succinate and consequent pseudohypoxic HIF- $1 \alpha$ stabilization, which drives, in turn, the engagement of an oncogenic program (103).

In addition to succinate-mediated regulation of the HIF- $1 \alpha$ activity, recent reports have highlighted a cross-link between succinate and epigenetics in cancer. Indeed, beyond PHDs, succinate acts as an inhibitor of other $\alpha$ KGDDs, such as the ten-eleven translocation proteins (TETs), a family of three enzymes catalyzing demethylation of cytosine residues on DNA (53) and the histone lysine demethylases (KDMs) (123)

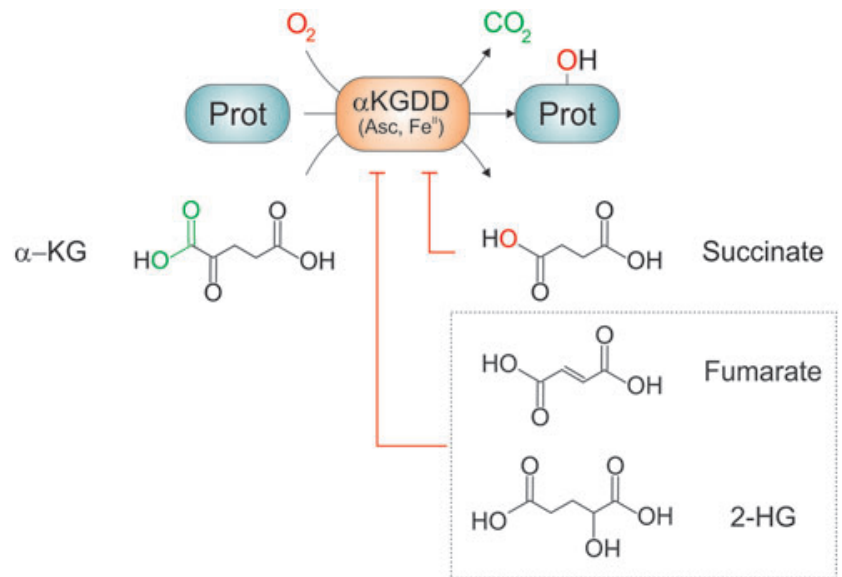

FIG. 3. Oncometabolic inhibition of $\alpha$-KG-dependent dioxygenases. The $\alpha$-KGDDs couple the hydroxylation of primary substrates with the decarboxylation of $\alpha-\mathrm{KG}$ to succinate and $\mathrm{CO}_{2}$, using $\mathrm{Fe}^{2+}$ and ascorbate as cofactors. The $\alpha$ KGDDs comprise an ever-expanding superfamily of more than 60 enzymes involved in collagen biosynthesis, oxygen sensing, fatty acids metabolism, DNA repair, and epigenetic remodeling. These enzymes can be inhibited by high levels of fumarate and 2 -HG in a competitive manner with $\alpha$-KG, and by succinate, via product inhibition. $\alpha-\mathrm{KG}, \alpha$-ketoglutarate; $\alpha \mathrm{KGDDs}$, $\alpha$-KG-dependent dioxygenases; 2-HG, 2-Hydroxyglutarate; Asc, ascorbate; Prot, protein. Color images are available online. involved in demethylation of histones (Fig. 4). Whereas DNA demethylation is usually tied to active gene transcription, histones methylation can be associated either with transcriptional repression or with gene expression. Interestingly, these epigenetic changes have been associated with the invasion potential of SDH-mutant tumors $(57,63)$. Collectively, this body of evidence points toward a tumorigenic role for SDH through the induction of both pseudohypoxic and hypermethylator phenotypes and confers on succinate a role as an oncometabolite.

Beyond promoting a pseudohypoxic environment, some pieces of evidences indicate that SDH might participate in tumorigenesis by altering intracellular redox homeostasis. Guzy et al. proposed a tumor-supportive role for reactive oxygen species (ROS) produced as a consequence of inhibition or hypoexpression of SDHB subunit in cancer cells (38). According to their model, ROS would be required for a complete inactivation of PHDs, thus contributing to promote HIF- $1 \alpha$ stabilization. Furthermore, a transgenic mouse cell line (SDHC E69), overexpressing the mutated $S d h c$ gene, was demonstrated to undergo higher rates of apoptosis, as a consequence of DNA damage induced by increased rates of superoxide production. However, the clones escaping cell death underwent transformation, acquiring the capability to form tumors when injected into immunocompromised mice (44).

\section{Fumarate hydratase}

FH is a homotetrameric enzyme of the TCA cycle catalyzing the reversible hydration of fumarate to malate. $F H$ gene encodes for mitochondrial and cytosolic isoforms of the protein, which differ in the peptide sequence of the N-terminal (128) and are generated either by differential mRNA processing (99) or by alternative initiation of gene transcription (26). Mutations in $F H$ gene have been reported in several human diseases (Fig. 2). Homozygous $F H$ inactivating mutations cause fumaric aciduria, an autosomal recessive metabolic disorder, associated with infantile encephalopathy and brain malformations (49). Germline heterozygous loss-of-function mutations in $\mathrm{FH}$ gene predispose to hereditary leiomyomatosis and renal cell cancer syndrome (HLRCC) $(54,114)$, a hereditary condition associated with benign tumors containing smooth muscle tissue (leiomyomas) in the skin, uterine fibroids, and aggressive type 2 papillary renal cancers. Likewise SDH in PGG/PHEO syndrome enzymatic activity of FH is absent in HLRCC as a consequence of loss of heterozygosity, leading to accumulation of fumarate in the transformed cell. In addition to hereditary mutational inactivation, sporadic $F H$ loss has been also reported in PGG, PHEO, neuroblastoma, glioma, ependymoma, osteosarcoma, Ewing sarcoma, and adenocortical carcinoma $(20,54,56,114)$.

Although $F H$ is considered as a tumor suppressor gene, how FH loss leads to malignant transformation is still unclear. Likewise succinate, fumarate also acts as an oncometabolite and exhibits extra-metabolic functions that can contribute to oncogenic transformation. FH loss-driven tumorigenesis has been associated with HIF- $1 \alpha$ stabilization. Indeed, since it is structurally similar to succinate, fumarate is also capable to inhibit PHDs activity, leading to pseudohypoxic HIF- $1 \alpha$ activation (Figs. 3 and 4) (43). In support of these data, HLRCC tumors overexpress HIF- $1 \alpha$ and the hypoxic-associated gene signature (87), and kidney- 

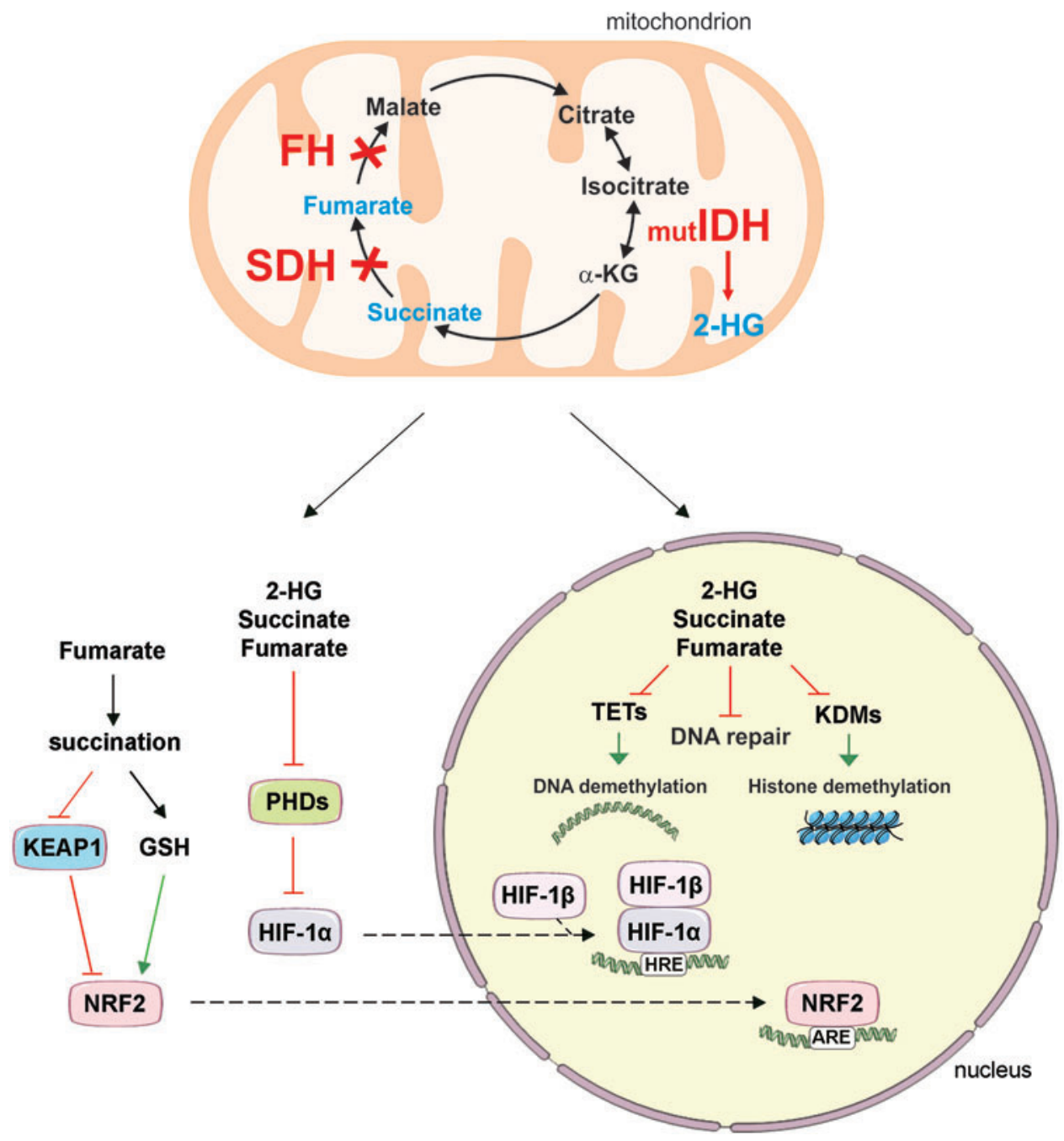

FIG. 4. Tumorigenic signaling mediated by oncometabolites accumulation. SDH and FH deficiency in cancer cells results in elevation of succinate and fumarate, respectively. Oncogenic mutations in genes encoding for IDH1 and IDH2 enzymes result in accumulation of 2-HG. In cytosol, such three oncometabolites can inhibit PHDs, which act as negative regulators of the stability of the transcription factor HIF- $1 \alpha$. Such inhibition results in the stabilization of HIF- $1 \alpha$, its nuclear translocation, dimerization with the oxygen-insentive subunit HIF-1 $\beta$, and binding on the HRE in the promoters of its target genes. In the nucleus such oncometabolites act as competitive inhibitors of the KDM family of histone demethylases and the TET family of DNA demethylases, thus driving tumorigenesis by altering cell epigenome and inhibiting DNA repair. Fumarate accumulation might also sustain tumorigenesis by stabilizing the transcription factor NRF2 through either a direct succination of its negative regulator KEAP1 or altering cell redox state, via succination of GSH. Once stabilized, NRF2 can bind ARE in the promoters of its target genes and drive the activation of antioxidant and anti-inflammatory transcriptional programs. ARE, antioxidant response elements; GSH, glutathione; HIF- $1 \alpha$, hypoxia-inducible factor- $1 \alpha$; HRE, hypoxia response elements; KDM, histone lysine demethylase; KEAP1, Kelch-like ECH-associated protein 1; NRF2, nuclear factor erythroid 2-like 2; PHD, prolyl-hydroxylases; TET, ten-eleven translocation protein. Color images are available online.

restricted inactivation of $F h 1$ gene in mice results in the formation of premalignant cysts upregulating HIF (88). Importantly, although kidney-specific FH loss causes the development of cysts in mice, it does not result in tumor formation, indicating that additional genetic hits to Fhl inactivation are likely to be required for renal cancer initiation (1). In line with this hypothesis, fumarate-induced senescence has been proposed as a mechanism restraining FH-deficient kidney cystic epithelia from transforming into hyperplastic lesions (130).

Besides inhibiting directly PHDs activity via fumarate accumulation, loss of FH in cancer cells drives HIF- $1 \alpha$ stabili- zation by altering intracellular iron homeostasis as well. Mechanistically, this results from a diminished expression of the DMT1 iron transporter, causing a cytosolic iron deficiency, elicited by the inhibition of the adenosine monophosphateactivated protein kinase (AMPK) (116). Lowering intracellular iron inhibits the iron-dependent activity of PHDs, resulting in $\mathrm{HIF}-1 \alpha$ stabilization, and activates the iron regulatory proteins, IRP1 and IRP2, negatively affecting the translation of HIF-2 $\alpha$ mRNA. Silencing of HIF- $1 \alpha$ or activation of AMPK decreases invasive activities of $\mathrm{FH}$-deficient cancer cells, indicating that HIF- $1 \alpha$ stabilization, elicited by AMPK suppression, supports the oncogenic growth of FH-deficient cells (116). 
Despite this body of evidence points toward a pivotal role of HIF in HLRCC, the contribution of such transcription factor to tumorigenesis is still debated. Indeed, genetic ablation of both Hifl and Hif2 in kidneys of Fhl-deficient mice does not prevent the formation of premalignant renal lesions, indicating that, at least in this model, HIF is dispensable for tumorigenesis (1).

In addition to PHDs, fumarate is capable to inhibit the activity of other $\alpha$ KGDDs, such as TETs and KDMs family of DNA and histone demethylases (Fig. 4) (123). Indeed, similar to succinate, fumarate also triggers epigenetic changes, thus regulating gene expression and eliciting oncogenic signaling cascades. In particular, by inhibiting TETs activity, fumarate induces hypermethylation and suppression of miR-200, a family of miRNAs inhibiting the expression of the transcription factors zinc-finger E-box binding homeobox 1/2 (ZEB1 and ZEB2) and snail homolog 2 (SNAI2), which promote an epithelialto-mesenchymal transition in cells, a process known to support cancer metastatization (102).

Similarly, by inhibiting two key regulators of DNA repair machinery, the lysine demethylases KDM4A and KDM4B, fumarate was demonstrated to suppress homologousrecombination repair pathway in HLRCC. Interestingly, as fumarate and succinate have similar structure and are known to converge in function, the accumulation of either oncometabolite promotes genomic instability in cells (110).

Beyond the competitive inhibition of $\alpha$ KGDDs, fumarate is able to drive covalent and irreversible amino acid modifications, thereby altering structure and function of proteins. Indeed, it is a mild electrophilic metabolite forming a thioether linkage with reactive thiols in a reaction of alkylation (Figs. 4 and 5). Prototypical example of such modification, named succination, is the alkylation of Kelch-like ECH-associated protein 1 (KEAP1) protein. KEAP1 is an E3 ubiquitin ligase, which prevents nuclear translocation of the transcription factor nuclear factor erythroid 2-like 2 (NFE2L2, or NRF2), priming it for the ubiquitine-proteasome degradation. NRF2 is a master regulator of antioxidant response. Upon redox unbalance or electrophilic stress, specific cysteine residues of KEAP1 are oxidized or alkylated (e.g., succinated) resulting in NRF2 stabilization and the activation of antioxidant program (98). Importantly, genetic targeting of NRF2 impairs KRas ${ }^{\mathrm{G} 12 \mathrm{D}}$-initiated pancreatic and lung tumorigenesis in mice, demonstrating that it controls an antioxidant and cellular detoxification program playing a pivotal role in oncogenesis (25).

Besides succinating KEAP1, fumarate was shown to activate NRF2 by additional mechanisms. Fumarate was demonstrated to engage NRF2-dependent antioxidant response by inducing the Abelson murine leukemia viral oncogene homolog 1 (ABL-1), which also contributes to sustain aerobic glycolysis in FH-deficient cells by activating the mTOR/ HIF $1 \alpha$ pathway (108). In support of these data, ABL-1 inhibitors suppress FH-deficient oncogenic cell growth (108).

NRF2 activation induced by FH loss can also result from redox unbalance elicited by succination of glutathione (GSH), representing the major thiol antioxidant in the cell (Fig. 4) (130). However, although the activation of the NRF2mediated antioxidant response has been demonstrated in $\mathrm{FH}$ deficient mice and cells $(1,108,130)$, the direct contribution of NRF2 to renal tumorigenesis and HLRCC still requires further exploration.
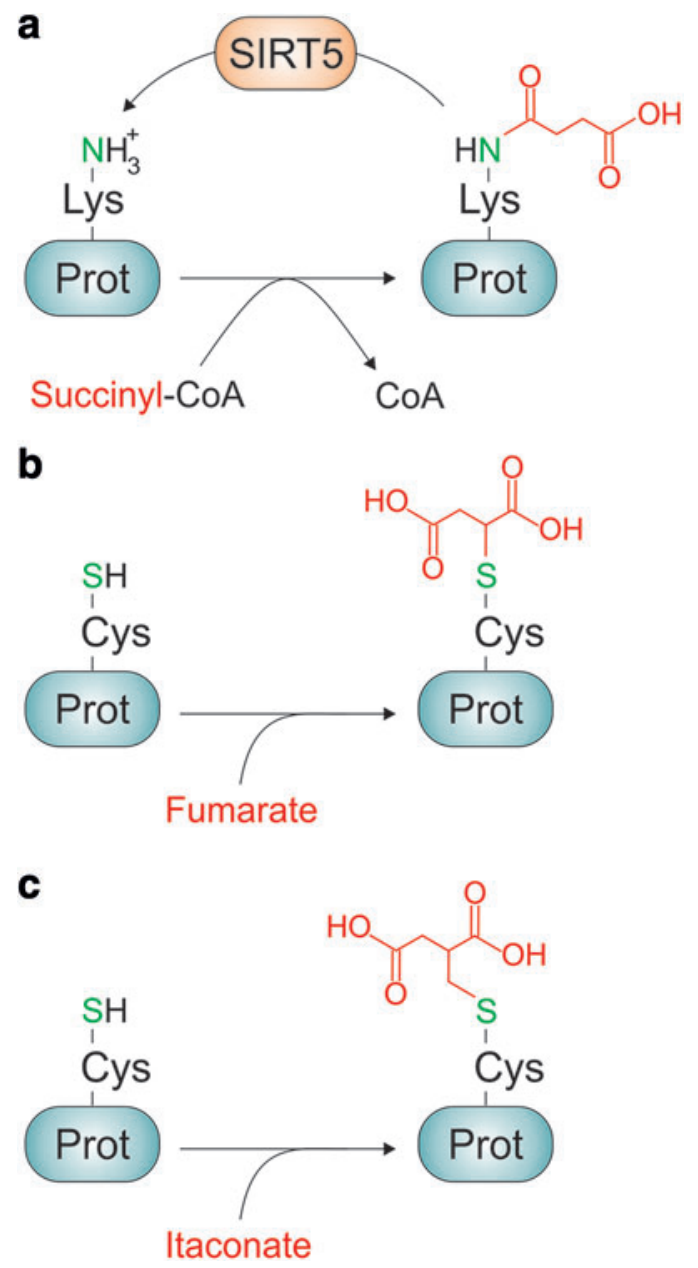

FIG. 5. PTMs induced by oncometabolites. Lysine succinylation (a) is a PTM caused by a nonenzymatic reaction between a lysine residue in a protein and succinylCoA. The reverse reaction is catalyzed by SIRT5, which acts as a NAD ${ }^{+}$-dependent desuccinylase. Succination (b) and 2,3-dicarboxypropylation (c) are modifications caused by a nonenzymatic reaction between a cysteine residue in a protein, or a low-molecular-weight thiol (e.g., GSH), and fumarate or itaconate, respectively. No reactions reversing those two cysteine adducts have been described occurring in cells. Overall, these modifications alter the structure of modified proteins, impacting on their function, stability, interaction with partners, and subcellular localization. PTM, post-translational modification. Color images are available online.

\section{Isocitrate dehydrogenase}

IDH catalyzes the reversible oxidative decarboxylation of isocitrate to $\alpha-\mathrm{KG}$ and $\mathrm{CO}_{2}$. Three isoforms of IDH have been described: IDH1 and IDH2 are $\mathrm{NADP}^{+}$-dependent homodimers localized, respectively, in the cytosol and in the mitochondrial matrix, whereas IDH3 is a $\mathrm{NAD}^{+}$-dependent heterotetrameric mitochondrial enzyme. IDH3 catalyzed reaction represents the rate-limiting step in the TCA cycle under physiological conditions, whereas IDH1 and IDH2 drive reductive carboxylation of $\alpha-\mathrm{KG}$, elicited by hypoxia and ETC dysfunction $(72,77)$. To date, no cancer-associated IDH3 mutations have been found; in contrast, IDH1 and IDH2 are mutated in several human tumors (Fig. 2). 
Somatic and heterozygous missense mutations in IDH1 and IDH2 are early genetic events in low-grade glioma, oligodendroglioma, grade IV glioblastoma, and grade II-III astrocytoma $(6,83,126)$. IDH1 and IDH2 mutations have also been reported in acute myeloid leukemia (AML), T cell lymphomas, prostate cancer, melanoma, and hepatocellular carcinoma (16, $68,69,127)$. IDH mutations also occur, with lower frequencies, in thyroid, breast, and colorectal cancer and in myelodysplastic syndrome and chondrosarcoma $(3,73)$.

Contrarily to hereditary inactivating mutations affecting $\mathrm{SDH}$ and $\mathrm{FH}$-encoding genes, mutations in $\mathrm{IDH} 1$ and $\mathrm{IDH} 2$ loci are somatic and neomorphic. In particular, the majority of such mutations affect the sequence encoding for the active sites of the enzymes and consist of changes in the amino acid residues R132 in IDH1 and either R172 or R140 in IDH2. Such mutations confer to IDH-mutant enzymes, the ability to produce the oncometabolite $2-\mathrm{HG}$ from $\alpha-\mathrm{KG}$, in an NADPHdependent manner $(24,121)$. Interestingly, 2-HG exists in nature in two enantiomeric forms, L-2-HG and D-2-HG. In physiological conditions, 2-HG levels are kept low due to their oxidation to $\alpha$-KG catalyzed by L/D-2-hydroxyglutarate dehydrogenases (L2HGDH and D2HGDH). Homozygous germline mutations of these two enzymes are responsible for L-2-hydroxyglutaric (L2-HGA) and D-2-hydroxyglutaric aciduria (D2-HGA), severe neurometabolic disorders associated with mental retardation, and lethality in childhood $(96,109)$. Interestingly, $50 \%$ of patients affected by D2-HGA do not have genetic defects in $\mathrm{D} 2 \mathrm{HGDH}$ but harbor mutations in $\mathrm{IDH} 2$ gene. Similar to this inborn error of metabolism, D-2-HG is the sole enantiomer produced by IDH mutants in brain cancer (115).

Differently from the other TCA-enzymes mutated in cancer, a more direct relationship between IDH mutations and tumorigenesis has been demonstrated. Indeed, the expression of IDH-mutant enzymes in several primary and immortalized cells in vitro is sufficient to stimulate proliferation, inhibit cellular differentiation, as well as induce cellular transformation when co-expressed with other oncogenes $(64,65$, 115). Importantly, the effects of mutant IDH enzymes on cellular growth and differentiation are fully recapitulated by the treatment of IDH wild-type cells with cell-permeable analogues of D-2-HG, indicating that the oncogenic effects depend on the neomorphic IDH activity $(8,65)$. It is worth to note that the expression of mutant IDH enzymes in mice, driven by the recombination of conditional IDH1- and IDH2-mutant knockin alleles, is not sufficient to promote tumorigenesis, demonstrating that additional genetic events, cooperating with IDH mutations are necessary to induce cancer formation in mice $(86,115)$.

Central to oncogenic effects of D-2-HG is its ability to competitively inhibit $\alpha$ KGDDs, such as TET2 and JmjC family of KDMs (Figs. 3 and 4). In such a way, IDH mutations progressively accumulate irreversible changes in the chromatin methylation landscape, altering normal cellular growth and differentiation programs $(23,65,125)$. A consequence of IDHdriven chromatin hypermethylation is the modification of chromatin topology, which, in turn, affects gene expression. Indeed, it has been recently found that IDH-mutant gliomas exhibit hypermethylation at CCCTC-binding factor (CTCF)binding sites, DNA sequences acting as insulators, blocking the interaction between enhancers and promoters. Such hypermethylation reduces CTCF binding to DNA and hampers the insulator activity, thereby allowing a constitutive enhancer to interact aberrantly with the receptor tyrosine kinase gene $P D G F R A$, a pivotal glioma oncogene (30). In addition to regulate cellular epigenetics, D-2-HG accumulation directly impacts on gene transcription. Indeed, glioma-derived mutations in IDH1 were demonstrated to inhibit PHDs, resulting in HIF-1 $\alpha$ stabilization (129).

A role for genetic instability has been also proposed in D-2-HG driven tumorigenesis (127). D-2-HG is known to inhibit ALKBH2 and ALKBH3, $\alpha$ KGDDs that repair alkylated single-stranded DNA and RNA containing 3-methylcytosine by oxidative demethylation. Indeed, IDH-mutant cells accumulate DNA double-stranded breaks and show increased sensitivity to alkylating agents (120). Furthermore, D-2-HG promotes DNA damage by altering the expression of genes involved in DNA repair, such as the DNA damage sensor ataxia telangiectasia mutated gene, by increasing repressive histone methylation markers on its promoter (42).

Beyond affecting DNA repair, D-2-HG may contribute to oncogenic events through other mechanistic ways. In lowgrade glioma, 2-HG is reported to activate mTOR signaling by inhibiting the histone demethylase KDM4A, which affect protein stability of DEPTOR, a negative regulator of mTOR complexes (17).

An additional oncogenic feature of D-2-HG relies on its ability to globally rewire tumor cell metabolism, regulating the function of several metabolic enzymes. Mutations in IDH were found to reprogram pyruvate and TCA cycle metabolism $(21,37,45)$. Intriguingly, D-2-HG has been found to be a competitive inhibitor of SDH complex, resulting in the accumulation of succinate, inhibition of mitochondrial respiration, and promotion of protein succinylation (58). Furthermore, D-2-HG can directly impair mitochondrial energy metabolism by inhibiting ATP synthase (33).

\section{Metabolic Vulnerabilities Imposed by TCA Cycle Defects in Cancer}

The TCA cycle is a fundamental housekeeping metabolic pathway. Therefore, its dysfunction, induced by oncogenic mutations in genes encoding for SDH, FH, and IDH enzymes, is expected to induce a wide range of adaptive metabolic rearrangements essential for cell survival. Importantly, since such metabolic adaptations are specific to mutated cells, they might represent cancer-specific liabilities exploitable for selective target therapies harming neoplastic cells, but sparing healthy tissues.

Technological advances in genome-wide profiling, untargeted metabolomics and functional genomics screenings, as well as the development of various machine learning pipelines for in silico predictions of synthetic lethal genetic interactions, have been efficiently used for identifying nutritional dependencies and metabolic vulnerabilities imposed by TCA cycle defects in cancer. By using unbiased metabolomics, we and others identified major nutritional requirements and metabolic adaptations to $\operatorname{SDH}$ loss $(19,66)$. Lack of $S d h b$ was shown to impair mitochondrial oxygen consumption and commit cells to ferment glucose for sustaining their energetic needs. Moreover, whereas SDHproficient cells show a net secretion of pyruvate in culture media, SDH loss commit cells to consume extracellular pyruvate. Consistent with this opposite metabolic exchange rate, pyruvate deprivation selectively impairs proliferation of 
SDH-deficient cells, sparing normal counterparts (19). Further investigations, employing stable-isotope-labeling approaches, revealed that consumption of exogenous pyruvate is required for the generation of aspartate, whose biosynthetic capacity in SDH-deficient cells is insufficient to meet their demand. Furthermore, SDH loss imposes dependency on pyruvate carboxylase (PC) to generate oxaloacetate, required for maintaining aspartate pool. Interestingly, as formerly predicted by a flux balance analysis-constrained computational modeling approach (31), PC silencing was demonstrated to selectively reduce proliferation $(19,66)$ and tumorigenic capacity of SDH-deficient cells, thus revealing pyruvate carboxylation as a vulnerability for potential treatment of SDH-associated malignancies (19).

In silico approaches were also exploited to identify metabolic liabilities in FH-deficient cells. FH loss was predicted to impose vulnerability to the inhibition of heme metabolism pathway (32). Consistent with the prediction, FH-deficient cells cultured in vitro were shown to secrete higher levels of bilirubin, a metabolite deriving from heme degradation. Moreover, silencing of heme oxygenase 1 (Hmox 1$)$, the rate-limiting enzyme in the catabolism of heme, reduced selectively growth of mouse Fhl-deficient cells. Similarly, pharmacological inhibition of HMOX1 activity, by the inhibitor zinc protoporphyrin, is effective in decreasing proliferative capacity of a human $\mathrm{FH}$ mutant cell line, sparing the isogenic FH-repleted cells (32). Functionally, re-routing fumarate precursors into the heme metabolism pathway may allow cells to produce NADH in the first steps of glutamine oxidation, despite the blockade of the TCA cycle induced by FH loss, to maintain mitochondrial potential and partial ATP generation by oxidative phosphorylation (OXPHOS).

Metabolomic profiling of FH-deficient cells enabled the identification of additional biochemical adaptations imposed TCA cycle truncation (131). It was shown that beyond fumarate, FH-deficient cells accumulate and secrete argininosuccinate, an intermediate of the urea cycle synthesized from aspartate and citrulline by argininosuccinate synthase (ASS1), in an ATP-dependent reaction. In normal cells, argininosuccinate is then converted to fumarate and arginine by argininosuccinate lyase (ASL). Such reaction links the urea cycle to the citric acid cycle, both discovered by Hans Krebs, in the so-called Krebs bicycle. However, fumarate accumulating in FH-deficient cells drives argininosuccinate production by the reversed ASL activity, thereby imposing a net consumption of exogenous arginine and an auxotrophy for this amino acid. Consistent with this, extracellular arginine degradation, catalyzed by pegylated arginine deaminase, decreased the intracellular levels of argininosuccinate, thereby decreasing both survival and proliferation of FH-deficient cells (131). In vivo validation of such vulnerabilities would drive the development of target therapies against malignancies driven by FH deficiency.

Two dropout functional genomic screenings enabled the identification of additional vulnerabilities in FH-deficient cells. The first screen returned genes encoding for adenylate cyclases, enzymes involved in the conversion of ATP to cAMP, as synthetic lethal with $F H$, suggesting that cAMPmediated signaling pathways may play a key role in the survival of FH-deficient cells (14). The second screen uncovered phosphogluconate dehydrogenase (PGD) as an enzyme essential for proliferation of FH-mutant cancer cells, both in vitro and in vivo. Mechanistically, PGD inhibition results in a blockade of glycolysis, suppression of reductive carboxylation of glutamine, and disrupts redox homeostasis by decreasing the $\mathrm{NADPH} / \mathrm{NADP}^{+}$ratio in $\mathrm{FH}$-deficient cells. Importantly, beyond elucidating a vulnerability imposed by FH loss, this study revealed a broad dependency on PGD in OXPHOS-deficient tumors (112).

By profiling the effect of oncogenic mutations in IDH1 and IDH2 genes on cellular metabolome, it was shown that IDH-mutant cells produce lower levels of branched-chain $\alpha$-ketoacids (BCKAs) compared with IDH-normal cells (91). This observation paved the way for the identification of metabolic vulnerabilities in IDH-mutant tumors (70). BCKAs are synthesized from leucine, isoleucine, and valine, three branched-chain amino acids (BCAAs), in reactions catalyzed by $\alpha$-KG-dependent BCAA transaminases, BCAT1 and BCAT2. Kaelin laboratory demonstrated that D-2-HG accumulating in IDH-mutant cells competitively inhibit BCAT1 and BCAT2 activity. Such bystander effect results in a decrease of intracellular levels of glutamate and an increased dependency on glutaminase activity for its biosynthesis. Importantly, as glutamate is the precursor of GSH, inhibition of glutaminase specifically sensitized IDH-mutant glioma cells to oxidative stress in vitro and to radiation in vitro and in vivo (70). Importantly, based on these findings, the National Cancer Institute Cancer Therapy Evaluation Program started a clinical trial for testing the combination of the glutaminase inhibitor CB-839 with radiation and temozolomide as novel therapeutic algorithm for the treatment of IDH1-mutant glioma patients.

Overall, these studies indicate that understanding fundamental metabolic reprogramming elicited by TCA cycle dysfunction might pave the way for the development of selective and effective intervention strategies for therapeutic benefit.

\section{TCA Cycle as a Signaling Hub Shaping Immunity}

Beyond acting as a factory of metabolites driving a plethora of potential oncogenic mechanisms, the TCA cycle controls function and plasticity of immune responses. TCA cycle oncometabolites (succinate, fumarate, and 2-HG) as well as a TCA cycle-associated intermediate, itaconate, have been demonstrated to have a transcriptional, epigenetic, and post-translational impact on the regulation of gene expression, which drives immune responses to pathogens and antigens stimulation as well as resolution of inflammation. Therefore, understanding the mechanisms of action of such onco-immunometabolites is crucial for identifying novel and effective intervention strategies against pathologies driven by either overactivation or exhaustion of immune system, such as inflammatory and autoimmune diseases, as well as obesity and cancer.

\section{Succinate}

The role of succinate in immunity has been primarily studied in macrophages cells of innate immunity playing a critical role in the initiation, maintenance, and resolution of inflammation, in response to pathogen or danger-associated molecular patterns recognition.

Ligation of Toll-like receptor 4 (TLR4) by lipopolysaccharide (LPS), a component of the outer membrane of gram- 
negative bacteria, results in classical (proinflammatory) macrophage activation, driven by NF- $\kappa \mathrm{B}$-dependent regulation of Hifla gene transcription and the consequent induction of a wide range of glycolytic genes $(48,93)$. In particular, LPS-induced HIF- $1 \alpha$ not only promotes glycolysis, which ensures a robust bioenergetic support in classically activated macrophages, but also sustains the expression of proinflammatory cytokines containing HRE sequences in their promoters, such as interleukin- $1 \beta$ (IL-1 $\beta$ ), a master regulator of the inflammatory response $(46,113)$. In line with these observations, myeloid deletion of Hifla gene results in a decreased production of proinflammatory mediators, such as the tumor necrosis factor- $\alpha$ (TNF- $\alpha$ ), IL- $1 \beta$, and IL- $1 \alpha$ production, and confers protection against LPS-induced lethality in mice $(62,85)$. Importantly, beyond inducing its gene expression, LPS can also promote HIF- $1 \alpha$ stabilization by increasing succinate levels in macrophages (113) (Fig. 6). Indeed, upon activation, macrophages undergo a complex metabolic reprogramming associated with an accumulation of succinate, whose carbons mainly derive from enhanced glutaminolysis, which proceeds via the GABA shunt (113). A consequence of succinate accumulation is its export in the cytosol followed by the inhibition of PHDs via product inhibition, resulting in the potentiation of inflammatory signaling and IL- $1 \beta$ expression, in a HIF- $1 \alpha$-dependent manner (113).

Beyond sustaining inflammatory signaling by competitive inhibition of PHDs activity, succinate activates HIF- $1 \alpha$ in macrophages by promoting mitochondrial ROS production (75) (Fig. 6). Indeed, inflammatory macrophages shift from producing ATP by OXPHOS to glycolysis. Low level of mitochondrial ATP synthesis, coupled with high level of succinate and an increase in mitochondrial membrane potential, induced by LPS stimulation, provide the thermodynamic force to stimulate flow of electrons, generated during SDH-mediated succinate oxidation, backward to mitochondrial complex I, rather than proceeding to complex III, as in resting conditions. This phenomenon, known as reverse electron transfer (RET), drives ROS production at level of complex I, which contribute to inhibit PHDs activity and stabilize HIF- $1 \alpha$. In line with this model, blocking ROS production with rotenone, a complex I inhibitor, or inhibiting succinate oxidation with dimethyl malonate (DMM), inhibits the inflammatory phenotype and promotes an anti-inflammatory outcome in LPS-stimulated macrophages (75).

A consequence of altered succinate metabolism in cells is the induction of lysine succinylation in proteins (Fig. 5). This posttranslational modification is caused by a direct reaction between a lysine residue and succinyl-CoA, whose levels increase as a consequence of succinate accumulation. Although this modification is likely to be nonenzymatic, the reverse reaction is catalyzed by SIRT5, which acts as a NAD ${ }^{+}$-dependent desuccinylase (28). Increased levels of succinylated proteins and a decrease in SIRT5 expression are observed in LPS-activated macrophages (95). A protein modified by lysine succinylation in macrophages is the glycolytic enzyme pyruvate kinase M2 (PKM2), demonstrated to be a physiological substrate of SIRT5 (119). In LPS-stimulated macrophages, succinylated PKM2 was shown to have lower pyruvate kinase activity and entry into the nucleus forming a complex with $\mathrm{HIF} 1 \alpha$ at the promoter of IL-1 $\beta$ gene, sustaining its expression (Fig. 6). Consistent with this, SIRT5-deficient mice boost IL- $1 \beta$ production and are more susceptible to colon inflammation (119).
Accumulation of succinate may be followed by secretion in the extracellular milieu where it can act as an autocrine or paracrine signaling agent, further amplifying inflammatory response (Fig. 6). Extracellular succinate is sensed by succinate receptor 1 (SUCNR1 or GPR91), a cell surface G-proteincoupled receptor. The expression of this receptor was found upregulated in macrophages stimulated either with LPS or with IL-1 $\beta$ (61). Importantly, SUCNR1-deficient macrophages release less IL- $1 \beta$ after LPS stimulation compared with normal counterparts (61). Collectively, these pieces of evidence suggest that extracellular succinate and SUCNR1 are involved in a positive feedback loop mechanism able to sustain inflammatory cytokines production (61).

Beyond macrophages, SUCNR1 was found playing a role in dendritic cells (DCs), which are critical for the engagement of an adaptive immune response. Triggering SUCNR1 enhances TNF- $\alpha$ and IL- $1 \beta$ expressions induced by several TLR ligands and promotes antigen-presenting capacity and migration of DCs (94), thus further supporting a role for succinate as proinflammatory metabolite (Fig. 6).

In line with its role in inflammation, aberrant succinate accumulation has been detected in a large variety of immunopathologies. For instances, succinate is elevated in the synovial fluid of the joints in patients affected by rheumatoid arthritis (41) and in serum of individuals affected by Crohn's disease, a pathology characterized by chronic intestinal inflammation (67). Interestingly, full body ablation of Sucnrl gene expression ameliorates morbidity in a mouse model of ulcerative colitis, suggesting that this receptor might be a target for therapeutic intervention in inflammatory bowel diseases (67).

Elevated levels of succinate were also found in the blood of obese humans and mice $(97,105)$. Interestingly, full body ablation of Sucnrl expression was shown to protect mice from diet-induced obesity (71), suggesting a pathogenic role for circulating succinate in development of such disease. However, these results do not fully reconcile with a recent study of Keiran et al. (47). Using mice with conditional ablation of Sucnrl gene in myeloid cells, this study demonstrates that succinate-SUCNR1 signaling promotes an anti-inflammatory phenotype in adipose-tissue-resident macrophages (ATMs) and increases susceptibility to diet-induced obesity. In line with these data, ATMs from obese subjects were found to downregulate $S U C N R 1$ expression. Therefore, loss of such anti-inflammatory circuit in obesity may contribute to the inability of obese adipocytes to resolve sustained inflammation and to restore tissue homeostasis (47).

Interestingly, anti-inflammatory SUCNR1 signaling was also reported in a mouse model of experimental autoimmune encephalomyelitis (EAE) (84). In this context, inflammatory mononuclear phagocytes release succinate, which activates SUCNR1 on neural stem cells (NSCs), enabling them to secrete prostaglandin E2 and scavenge extracellular succinate, eliciting subsequent anti-inflammatory effects. Somatic NSCs transplantation is known to improve clinicopathological features of animal models of inflammatory central nervous system disorders, by suppressing inflammation. Consistent with the anti-inflammatory program elicited by SUCNR1 expression in NSCs, transplantation of Sucnrlablated NSCs shows impaired ability to ameliorate chronic neuroinflammation (84). Collectively, these results suggest that the role of SUCNR1 in inflammatory diseases might be 


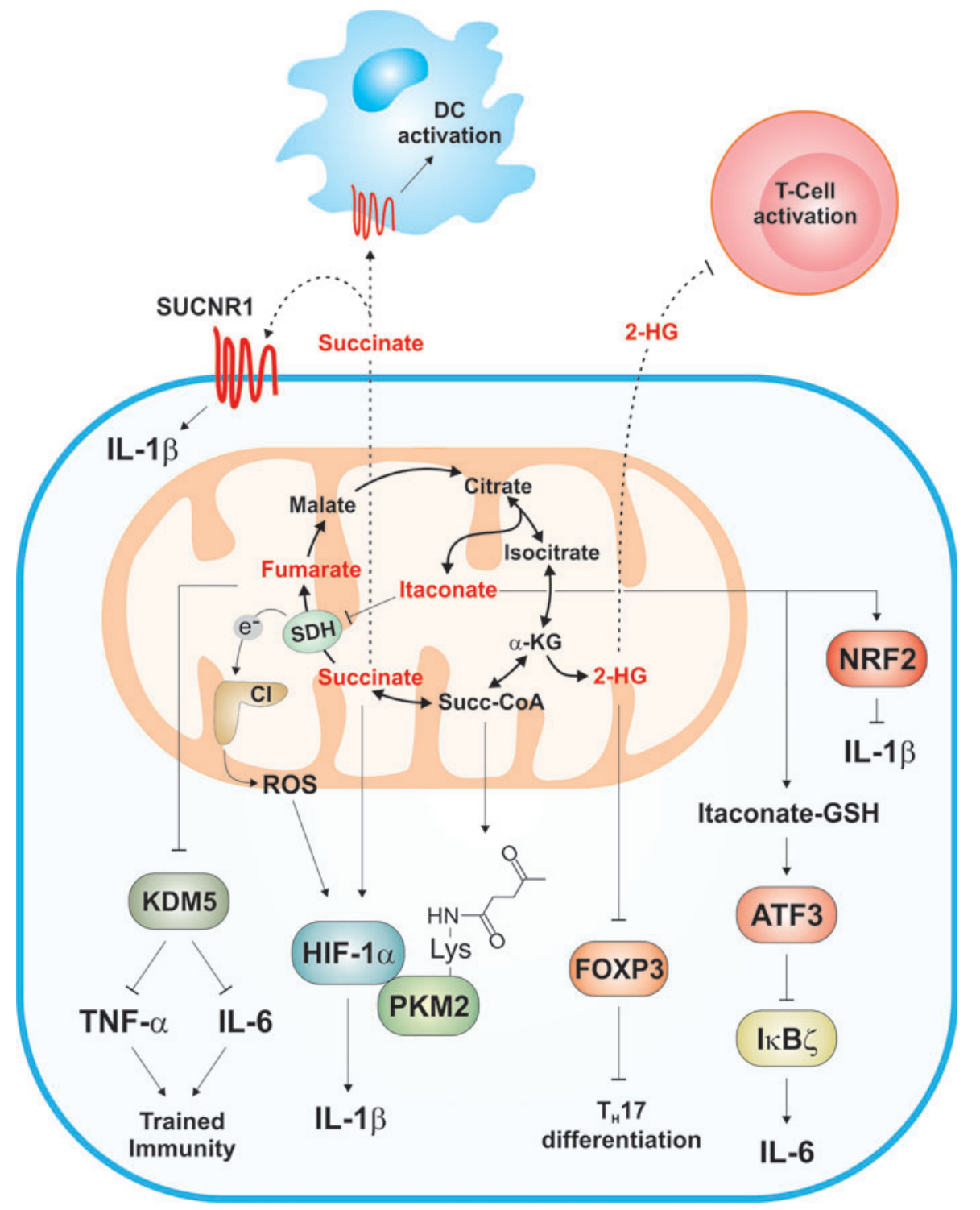

FIG. 6. TCA cycle oncometabolites act as signaling agents to shape immune cell functions. Upon LPS stimulation, macrophages accumulate succinate, which stabilizes HIF- $1 \alpha$ via product inhibition of PHDs activity. ROS produced by the reverse flow of electrons, generated during succinate oxidation, to mitochondrial complex I, may also contribute to inhibit PHDs activity and stabilize HIF- $1 \alpha$. Once stabilized, HIF- $1 \alpha$ stimulates transcription of $I l l b$ gene by direct binding to HRE in its promoter. LPS-stimulated macrophages show increased levels of succinylated proteins resulting from succinate accumulation and decreased activity of SIRT5, which acts as a protein desuccinylase. Succinylated PKM2 acts as a transcriptional coactivator through binding to HIF- $1 \alpha$ at the promoter of IL- $1 \beta$ gene. Succinate may also be released by macrophages and bind the G-protein-coupled succinate receptor (SUCNR1) at the plasma membrane. SUCNR1 activation synergizes with TLR ligands to increase IL- $1 \beta$ expression and its own gene expression. SUCNR1 ligation on DCs promotes antigen-presenting capacity and their migration. LPS-stimulated macrophages accumulate itaconate, synthesized by IRG1/ ACOD1 from cis-aconitate. Itaconate limits macrophage activation by inhibiting SDH activity in the mitochondria. In cytosol, itaconate alkylates reactive cysteines residues of KEAP1 and GSH in a reaction of 2,3-dicarboxypropylation. Such modifications trigger the activation of the anti-inflammatory and antioxidant transcription factor NRF2 and ATF3. NRF2 activation results in repression of $I l 1 b$ gene expression, whereas activation of ATF3 inhibits I $\kappa \mathrm{B} \zeta$-dependent IL- 6 induction. Accumulation of fumarate in monocytes treated with $\beta$-glucan, known to elicit immune training, inhibits the activity of KDM5 histone demethylases, which negatively regulate the expression of TNF- $\alpha$ and IL-6. In T helper cells, 2-HG accumulation results in hypermethylation of Foxp3 promoter and inhibition of its gene expression, thus triggering the differentiation toward $\mathrm{T}_{\mathrm{H}} 17$ phenotype. D-2-HG released by IDHs-mutant cells in the extracellular milieu can be taken up by $\mathrm{T}$ cells and inhibit their proliferation and effector functions, upon activation. Dotted arrows indicate extracellular release of the indicated metabolites and their autocrine/paracrine functions. ACOD1, aconitate decarboxylase 1; ATF3, activating transcription factor 3; DCs, dendritic cells; $\mathrm{I} \kappa \mathrm{B} \zeta$, inhibitor of nuclear factor kappa B zeta; IL-1 $\beta$, interleukin-1 $\beta$; IL-6, interleukin 6; IRG1, immunoresponsive gene 1; PKM2, pyruvate kinase M2; ROS, reactive oxygen species; SUCNR1, succinate receptor $1 ; \mathrm{T}_{\mathrm{H}} 17$, T helper 17 ; TNF- $\alpha$, tumor necrosis factor- $\alpha$. Color images are available online. 
more complex than initially thought and highlight the importance of using conditional knockout mouse models to adequately define the impact of extracellular succinate on individual cell types, both in physiological and in pathological conditions.

\section{Fumarate}

Similar to succinate, fumarate also accumulates in classically activated macrophages $(51,73)$. Integrating transcriptional and metabolomics data, the induction of the argininosuccinate shunt was proposed as the metabolic pathway mainly accounting for the elevated fumarate levels. Similar to succinate, treatment of LPS-stimulated mouse bone marrow-derived macrophage cultures with fumarate was shown to stimulate release of proinflammatory cytokines (75). Contrarily, in another study, cell-permeable fumaric esters were demonstrated to blunt IL- $1 \beta$ production in mouse peritoneal macrophages activated by LPS, by inhibiting, via succination, the activity of glyceraldehyde 3phosphate dehydrogenase (GAPDH), enzyme catalyzing a ratelimiting step of glycolysis (51). This modification was also shown to occur in peripheral blood mononuclear cells isolated from multiple sclerosis (MS) patients treated with dimethyl fumarate (DMF) (51). However, on the basis of these nonunifying data, the precise role of fumarate accumulation in classically activated macrophages needs further clarification.

Fumarate has been recently highlighted as an important signal in trained immunity, a property of innate immune cells enabling enhanced responsive capacity to re-invading pathogens, independent of classical adaptive immune memory $(4,107)$. Such innate training program is mediated by longlasting epigenetic changes elicited in the innate immune cells after the first encounter with the microbe, enabling their enhanced responsiveness if restimulated. Accumulation of fumarate in monocytes treated with $\beta$-glucan, a component of Candida albicans known to elicit immune training, was identified as instrumental for enhancing interleukin 6 (IL-6) and TNF- $\alpha$ production, upon restimulation with LPS (4) (Fig. 6). Using a cell-permeable analogue, monomethyl fumarate, this effect was demonstrated to be dependent on the inhibition of the activity of KDM5 histone demethylase, resulting in consequent increased levels of $\mathrm{H} 3 \mathrm{~K} 4 \mathrm{me} 3$, a histone methylation marker of active gene expression, at the promoters of both Tnf and Il6 genes (4). Importantly, fumaratemediated effects can be neutralized by $\alpha-K G$, which serves as substrate for such enzyme, suggesting that ratios between these two TCA cycle metabolites might have a critical role in training immune responses.

\section{2-Hydroxyglutarate}

2-HG has recently emerged as an epigenetic modifier governing $\mathrm{T}$ cell differentiation. $\mathrm{T}$ helper $17\left(\mathrm{~T}_{\mathrm{H}} 17\right)$ cells and regulatory $\mathrm{T}$ (Treg) cells are subset of $\mathrm{T}$ helper cells, deriving from naive $\mathrm{CD}^{+} \mathrm{T}$ lymphocytes, with opposite functions: the former are proinflammatory, the latter immunosuppressive. The forkhead box P3 (FOXP3) is a transcription factor driving Tregs development. On the contrary, it inhibits cell fate toward $\mathrm{T}_{\mathrm{H}} 17$ phenotype. $\mathrm{Xu}$ et al. reported higher levels of $2-\mathrm{HG}$ in $\mathrm{T}_{\mathrm{H}} 17$ cells, with respect to Treg cells (124). 2-HG accumulation, although at lower levels with respect to those detected in IDH-mutated cancer cells, results in hypermethylation of Foxp3 gene and inhibition of its expression, effects mediated by inhibition of TETs DNA demethylases (124) (Fig. 6). Mechanistically, 2-HG production is sustained by $\alpha-\mathrm{KG}$ biosynthesis catalyzed by the aspartate aminotransferase GOT1. Indeed, pharmacological inhibition of this enzyme by aminooxyacetic acid (AOAA) decreases 2-HG levels and triggers differentiation of $\mathrm{T}_{\mathrm{H}} 17$ cells to Tregs, by promoting Foxp3 transcription. In line with these results, AOAA was shown to improve progression of a mouse model of $\mathrm{MS}$, a neuroinflammatory disease where $\mathrm{T}_{\mathrm{H}} 17$ cells play instrumental pathogenic roles (124).

Beyond dictating fate of $\mathrm{T}$ cells, a role for $2-\mathrm{HG}$ as prototypic oncometabolite regulating the tumor immune microenvironment has been recently identified (15). Platten laboratory demonstrated that exogenous D-2-HG can be efficiently taken up by $\mathrm{T}$ cells via sodium-dependent and organic anion transporters. Internalized D-2-HG inhibits the proliferation and effector functions of activated $\mathrm{T}$ cells (Fig. 6). Mechanistically, this results from perturbation of the activity of NFAT, a transcription factor regulating the expression of key immune response-related genes in T cells, as well as by inhibition of polyamine biosynthesis. Consistent with these in vitro evidence, tumor-infiltrating lymphocytes are less abundant and exhibit decreased proliferation in gliomas expressing Idhl mutations with respect to Idhl wildtype counterparts. Importantly, IdhI-mutant-derived R-2-HG was shown to block immunotherapy-mediated antitumor immune responses, whereas inhibition of R-2-HG biosynthesis potentiates antitumor immunity induced by checkpoint inhibition or an IDH1-specific vaccine (15).

\section{Itaconate}

Itaconate is a TCA cycle-derived metabolite with crucial anti-inflammatory functions in innate immune cells. It is a fivecarbon metabolite produced in a reaction of decarboxylation of cis-aconitate catalyzed by the mitochondrial enzyme aconitate decarboxylase 1 (ACOD1, also known as CAD). Acod1 gene was cloned in late 90 s and originally called immunoresponsive gene 1 (Irg1), as found dramatically induced in LPS-activated macrophages (55). However, the role of such gene in itaconate biosynthesis was only identified almost two decades later (74). Despite itaconate was long known for its antibacterial function, due to its ability to inhibit isocitrate lyase, a bacterial glyoxylate shunt enzyme, its function in macrophage biology, has been revealed only recently (52). In particular, Artyomov laboratory first demonstrated that pretreatment of classically activated mouse bone marrow-derived macrophages (BMDMs) with a methyl ester derivative of itaconate, dimethyl itaconate (DI), inhibits secretion of proinflammatory cytokines. In support of this evidence, increased HIF- $1 \alpha$ and IL- $1 \beta$ levels were observed in Irg 1-deficient BMDMs stimulated with LPS (Fig. 6). Mechanistically, it was suggested that anti-inflammatory properties of itaconate might be dependent on competitive inhibition of SDH activity, thereby blocking ROS generation derived from RET, as previously described. Consistent with this model, LPS-activated IRG1-deficient BMDMs display attenuated succinate accumulation and increased oxygen consumption rates (52).

Sharing structural similarity to other electrophilic metabolites (e.g., fumarate), itaconate was thought to be able to alkylate cysteine residues (Fig. 5). This hypothesis was confirmed by O'Neill and co-workers who demonstrated that 
itaconate can form adduct with reactive thiols in a reaction of 2,3-dicarboxypropylation. The occurrence of such modification on reactive thiols of KEAP1 was shown to be triggered by treatment of BMDMs with a cell permeable analogues of itaconate, such as DI and 4-octyl itaconate (4-OI), and to be sufficient for stabilizing NRF2 and activating its antioxidant and anti-inflammatory transcriptional program $(50,76)$ (Fig. 6). This finding was substantiated by Bambouskova et al. who reported almost a complete abrogation of LPS-induced NRF2 stabilization in IRG1-null macrophages, confirming that endogenous itaconate might stabilizes NRF2 (7). However, this study suggested that the inhibition of KEAP1 might depend on ability of itaconate to alkylate and deplete GSH, event resulting in intracellular redox unbalance and an adaptive increase in NRF2 activity to counteract this alteration (7). The same study also demonstrated that itaconate can inhibit secondary transcriptional responses to LPS, such as IL-6 production, by decreasing the levels of the transcription factor inhibitor of nuclear factor kappa B zeta $(\mathrm{I} \kappa \mathrm{B} \zeta)$. This inhibition was shown to be mediated by the transcription factor ATF3 (activating transcription factor 3) and to be NRF2independent. Importantly, although the occurrence of this effect is highly pronounced upon treatment of classically activated macrophages with pharmacological doses of DI, it may be also elicited physiologically by endogenously synthesized itaconate in LPS-tolerized macrophages (7) (Fig. 6). Tolerized macrophages are characterized by reduced response capacity to a second LPS stimulation. This phenomenon is crucial for limiting tissue damage during sepsis but might lead to a detrimental immunoparalysis, increasing sensitivity to potential secondary infections. It is worth to note that immunoparalysis can be counteracted by immune training. Consistent with the instrumental role of itaconate in immune tolerance, treatment of human monocytes with DI was shown to inhibit $\beta$-glucan-induced onset of trained immunity. In line with this, $\beta$-glucan was found to impair LPS-induced expression of IRG1 in monocytes, thus providing a further evidence on the role of itaconate in modulating innate immune responses (27).

It is worth noting that most of current understanding about the role of itaconate in immunobiology has been generated using some ester derivatives such as 4-ethyl itaconate, DI, and 4-OI to deliver itaconate intracellularly. The need to employ such derivatives derives by the lack of evidence for a cell surface transporter, which might mediate itaconate uptake. However, recent studies demonstrated that extracellular itaconate might be imported in cells, such as adipocytes (106) and macrophages (89), down a concentration gradient. Contrarily, DI has been recently reported not to be metabolized to itaconate in cells (29) and LPS stimulation to be required for metabolism of 4-OI to itaconate in murine macrophages $(59,76)$. Furthermore, esterification is predicted to increase itaconate electrophilicity, which might alter its reactivity toward thiol groups. As a consequence, results generated by employing itaconate analogues might not be representative of the actual biological effects elicited by endogenously produced metabolite. Therefore, caution and appropriate controls would be necessary to determine whether effects observed with itaconate derivatives are itaconate-dependent. In this respect, models lacking Irg1 expression should always be used to validate such effects.

Beyond the resolution of inflammation, itaconate plays a role in reprogramming the microenvironment of tumors. Untargeted metabolomic profiling identified itaconate as one of the most highly accumulated metabolites in peritoneal macrophages sorted from mice bearing peritoneal tumors compared with naive counterparts. Importantly, the transplant of IRG1-silenced macrophages in tumor-bearing mice decreased tumor burden. Although the mechanisms mediating tumor-induced intaconate accumulation were not uncovered, this study demonstrated that IRG1 expression in peritoneal resident macrophages sustains MAPK activation in tumors in an ROS-dependent manner, thus corroborating a paracrine tumor-promoting role for this metabolite (122).

\section{The TCA Cycle as an Actionable Metabolic Pathway in Immunopathology}

The identification of instrumental roles of TCA cycle intermediates in shaping immune responses has driven the interest in developing therapeutic strategies against immunopathologies, based on the delivery of cell-permeable forms of such metabolites.

DMF is the methyl ester of fumarate. It was initially licensed - trade name Fumaderm ${ }^{\circledR}$ —as an oral therapy for psoriasis, a type-1 cytokine-mediated chronic autoimmune skin disease driven by the infiltration of Th1/Th17 cells into the skin. Since 2013, DMF — trade name Tecfidera ${ }^{\circledR}$ — has been used to treat adult individuals with relapsing MS, a chronic inflammatory autoimmune disease driven by $\mathrm{T}$ cell-mediated demyelination of nerve cell axons in the brain and spinal cord. In both pathologies, DMF elicits systemic anti-inflammatory effects by blunting both number and proinflammatory phenotype of $\mathrm{T}$ cells. The mechanism of action of DMF relies on activation of NRF2-mediated antioxidant and anti-inflammatory pathways, inhibiting Th1 and Th17 responses, as well as promoting Th2 responses (2).

Beyond acting on T cells, DMF shows immunomodulatory effects on immune cells of the innate compartment. DMF was reported to induce formation of type II (anti-inflammatory) DCs in MS patients and in mice developing EAE, improving disease morbidity (34). Mechanistically, this effect was mainly due to fumarate-mediated GSH depletion, resulting in increased hemoxygenase-1 expression, which, in turn, inhibits NF- $\kappa \mathrm{B}$-mediated transcription of IL-23, cytokine produced by type I (pro-inflammatory) DCs promoting pathogenic $\mathrm{T}$ helper cell differentiation (34).

Beyond fumarate, mimetics of itaconate, such as DI and 4OI, also have been shown to ameliorate conditions in several inflammatory diseases. 4-OI offered protection in a mouse model of septic shock, decreasing IL- $1 \beta$ and TNF- $\alpha$ production and increasing survival (76). DI was shown to ameliorate psoriasis in mice induced by the TLR7 agonist imiquimod, and mechanistically, this effect was dependent on inhibition of $\mathrm{I} \kappa \mathrm{B} \zeta(7)$.

Another lipophilic derivative with potent systemic antiinflammatory activity is DMM, which is rapidly hydrolyzed within the cell to generate malonate and act as competitive inhibitor of SDH. DMM offered protection to ischemiareperfusion (IR) injury (22). As demonstrated by Murphy laboratory, succinate accumulates upon ischemia, whereas it is rapidly reoxidized by SDH upon reperfusion, thus driving extensive mitochondrial superoxide generation by RET at the mitochondrial complex I, responsible for tissue damage. Inhibition of SDH during ischemia, by pretreating tissues with DMM, was sufficient to prevent ischemic succinate accumulation and to protect against infarction upon reperfusion 
(22). Interestingly, beyond DMM, SDH activity is also inhibited by DI. Therefore, it is not surprising that, likewise DMM, DI could also decrease IR injury (52).

It is worth to note that the mechanism of ROS production by succinate oxidation in classically activated macrophages seems to be similar to that responsible for tissue injury evoked by IR (76). Consistent with this, DMM was also found to decrease inflammation in a mouse model of sepsis (76).

\section{Conclusions and Future Perspectives}

The body of knowledge outlined in this review indicates the TCA cycle as a core metabolic platform for oncogenic signaling and a rheostat for immune responses. More in general, uncovering the post-translational and epigenetic impact of oncometabolites accumulation in cancer and immune cells revealed that the TCA cycle acts as an indicator of mitochondrial status, engaging dicarboxylates as messengers for dialoguing with the nucleus. However, some critical points should be considered, and several questions still remain to be answered. For example, understanding the subcellular localization of TCA cycle oncoimmunometabolites accumulation and the time-resolved determination of their ratios could contribute to better define their function in tuning the immune responses. Similarly, further exploring the mechanisms of their paracrine signaling might allow us to extend our understanding of the impact of such metabolites in reprogramming the immune microenvironment of tumors.

Finally, mutational TCA cycle dysfunction in cancer paved the way for uncovering metabolic adaptations serving as potential targets for therapeutic interventions. However, despite the identified vulnerabilities are specific to mutated cells, some issues could limit their clinical translation. First, it is likely that harnessing adaptive metabolic pathways will lead to further metabolic rewiring. Therefore, deciphering metabolic changes cooperating with TCA cycle dysfunction in initiating neoplastic transformation is crucial to identify genuine liabilities, hardly to be escaped by resistance mechanisms. Moreover, it is possible to hypothesize that, within a solid tumor, cancer cells sharing similar tumorinitiating metabolic aberrations might exhibit heterogeneous nutritional dependencies, dictated by the microenvironment in which they are localized. Therefore, understanding how TCA cycle dysfunction imposes metabolic rewiring in response to nutrient availability of cancer niches might provide additional strategies to tailor interventions for improved clinical benefit.

\section{Funding Information}

The research leading to these results has received funding from AIRC under Start-Up 2017-ID. 20464 project-PI S.C. and from Bando della Ricerca Finalizzata 2018 GR2018-12365954 to S.C.

\section{References}

1. Adam J, Hatipoglu E, O'Flaherty L, Ternette N, Sahgal N, Lockstone H, Baban D, Nye E, Stamp GW, Wolhuter K, Stevens M, Fischer R, Carmeliet P, Maxwell PH, Pugh CW, Frizzell N, Soga T, Kessler BM, El-Bahrawy M, Ratcliffe PJ, and Pollard PJ. Renal cyst formation in Fh1deficient mice is independent of the Hif/Phd pathway: roles for fumarate in KEAP1 succination and Nrf2 signaling. Cancer Cell 20: 524-537, 2011.

2. Al-Jaderi Z and Maghazachi AA. Utilization of dimethyl fumarate and related molecules for treatment of multiple sclerosis, cancer, and other diseases. Front Immunol 7: 278, 2016.

3. Amary MF, Bacsi K, Maggiani F, Damato S, Halai D, Berisha F, Pollock R, O'Donnell P, Grigoriadis A, Diss T, Eskandarpour M, Presneau N, Hogendoorn PCW, Futreal A, Tirabosco R, and Flanagan AM. IDH1 and IDH2 mutations are frequent events in central chondrosarcoma and central and periosteal chondromas but not in other mesenchymal tumours. J Pathol 224: 334-343, 2011.

4. Arts RJW, Novakovic B, ter Horst R, Carvalho A, Bekkering S, Lachmandas E, Rodrigues F, Silvestre R, Cheng S-C, Wang S-Y, Habibi E, Gonçalves LG, Mesquita I, Cunha C, van Laarhoven A, van de Veerdonk FL, Williams DL, van der Meer JWM, Logie C, O'Neill LA, Dinarello CA, Riksen NP, van Crevel R, Clish C, Notebaart RA, Joosten LAB, Stunnenberg HG, Xavier RJ, and Netea MG. Glutaminolysis and fumarate accumulation integrate immunometabolic and epigenetic programs in trained immunity. Cell Metab 24: 807-819, 2016.

5. Astuti D, Latif F, Dallol A, Dahia PL, Douglas F, George E, Sköldberg F, Husebye ES, Eng C, and Maher ER. Gene mutations in the succinate dehydrogenase subunit SDHB cause susceptibility to familial pheochromocytoma and to familial paraganglioma. Am J Hum Genet 69: 49-54, 2001.

6. Balss J, Meyer J, Mueller W, Korshunov A, Hartmann $\mathrm{C}$, and von Deimling A. Analysis of the IDH1 codon 132 mutation in brain tumors. Acta Neuropathol 116: 597602, 2008.

7. Bambouskova M, Gorvel L, Lampropoulou V, Sergushichev A, Loginicheva E, Johnson K, Korenfeld D, Mathyer ME, Kim H, Huang L-H, Duncan D, Bregman H, Keskin A, Santeford A, Apte RS, Sehgal R, Johnson B, Amarasinghe GK, Soares MP, Satoh T, Akira S, Hai T, de Guzman Strong C, Auclair K, Roddy TP, Biller SA, Jovanovic M, Klechevsky E, Stewart KM, Randolph GJ, and Artyomov MN. Electrophilic properties of itaconate and derivatives regulate the $\mathrm{I} \kappa \mathrm{B} \zeta-\mathrm{ATF} 3$ inflammatory axis. Nature 556: 501-504, 2018.

8. Bardella C, Al-Dalahmah O, Krell D, Brazauskas P, AlQahtani K, Tomkova M, Adam J, Serres S, Lockstone H, Freeman-Mills L, Pfeffer I, Sibson N, Goldin R, SchusterBöeckler B, Pollard PJ, Soga T, McCullagh JS, Schofield CJ, Mulholland P, Ansorge O, Kriaucionis S, Ratcliffe PJ, Szele FG, and Tomlinson I. Expression of Idh1R132H in the murine subventricular zone stem cell niche recapitulates features of early gliomagenesis. Cancer Cell 30: 578-594, 2016.

9. Bardella C, Pollard PJ, and Tomlinson I. SDH mutations in cancer. Biochim Biophys Acta 1807: 1432-1443, 2011.

10. Bayley J-P, Kunst HPM, Cascon A, Sampietro ML, Gaal J, Korpershoek E, Hinojar-Gutierrez A, Timmers HJLM, Hoefsloot LH, Hermsen MA, Suárez C, Hussain AK, Vriends AHJT, Hes FJ, Jansen JC, Tops CM, Corssmit EP, de Knijff P, Lenders JWM, Cremers CWRJ, Devilee P, Dinjens WNM, de Krijger RR, and Robledo M. SDHAF2 mutations in familial and sporadic paraganglioma and phaeochromocytoma. Lancet Oncol 11: 366-372, 2010.

11. Baysal BE. A recurrent stop-codon mutation in succinate dehydrogenase subunit B gene in normal peripheral blood 
and childhood T-cell acute leukemia. PLoS One 2: e436, 2007.

12. Baysal BE, Ferrell RE, Willett-Brozick JE, Lawrence EC, Myssiorek D, Bosch A, van der Mey A, Taschner PE, Rubinstein WS, Myers EN, Richard CW, Cornelisse CJ, Devilee P, and Devlin B. Mutations in SDHD, a mitochondrial complex II gene, in hereditary paraganglioma. Science 287: 848-851, 2000.

13. Baysal BE, Willett-Brozick JE, Lawrence EC, Drovdlic CM, Savul SA, McLeod DR, Yee HA, Brackmann DE, Slattery WH, Myers EN, Ferrell RE, and Rubinstein WS. Prevalence of SDHB, SDHC, and SDHD germline mutations in clinic patients with head and neck paragangliomas. J Med Genet 39: 178-183, 2002.

14. Boettcher M, Lawson A, Ladenburger V, Fredebohm J, Wolf J, Hoheisel JD, Frezza C, and Shlomi T. High throughput synthetic lethality screen reveals a tumorigenic role of adenylate cyclase in fumarate hydratase-deficient cancer cells. BMC Genomics 15: 158, 2014.

15. Bunse L, Pusch S, Bunse T, Sahm F, Sanghvi K, Friedrich M, Alansary D, Sonner JK, Green E, Deumelandt K, Kilian M, Neftel C, Uhlig S, Kessler T, von Landenberg A, Berghoff AS, Marsh K, Steadman M, Zhu D, Nicolay B, Wiestler B, Breckwoldt MO, Al-Ali R, Karcher-Bausch S, Bozza M, Oezen I, Kramer M, Meyer J, Habel A, Eisel J, Poschet G, Weller M, Preusser M, Nadji-Ohl M, Thon N, Burger MC, Harter PN, Ratliff M, Harbottle R, Benner A, Schrimpf D, Okun J, Herold-Mende C, Turcan S, Kaulfuss S, Hess-Stumpp H, Bieback K, Cahill DP, Plate KH, Hänggi $\mathrm{D}$, Dorsch M, Suvà ML, Niemeyer BA, von Deimling A, Wick W, and Platten M. Suppression of antitumor T cell immunity by the oncometabolite (R)-2-hydroxyglutarate. Nat Med 24: 1192-1203, 2018.

16. Cairns RA, Iqbal J, Lemonnier F, Kucuk C, de Leval L, Jais J-P, Parrens M, Martin A, Xerri L, Brousset P, Chan LC, Chan W-C, Gaulard P, and Mak TW. IDH2 mutations are frequent in angioimmunoblastic $\mathrm{T}$-cell lymphoma. Blood 119: 1901-1903, 2012.

17. Carbonneau M, Gagne LM, Lalonde ME, Germain MA, Motorina A, Guiot MC, Secco B, Vincent EE, Tumber A, Hulea L, Bergeman J, Oppermann U, Jones RG, Laplante M, Topisirovic I, Petrecca K, Huot MÉ, and Mallette FA. The oncometabolite 2-hydroxyglutarate activates the mTOR signalling pathway. Nat Commun 7: 12700, 2016.

18. Cardaci S and Ciriolo MR. TCA cycle defects and cancer: when metabolism tunes redox state. Int J Cell Biol 2012: 161837, 2012.

19. Cardaci S, Zheng L, MacKay G, van den Broek NJF, MacKenzie ED, Nixon C, Stevenson D, Tumanov S, Bulusu V, Kamphorst JJ, Vazquez A, Fleming S, Schiavi F, Kalna G, Blyth K, Strathdee D, and Gottlieb E. Pyruvate carboxylation enables growth of SDH-deficient cells by supporting aspartate biosynthesis. Nat Cell Biol 17: 13171326, 2015.

20. Carvajal-Carmona LG, Alam NA, Pollard PJ, Jones AM, Barclay E, Wortham N, Pignatelli M, Freeman A, Pomplun S, Ellis I, Poulsom R, El-Bahrawy MA, Berney DM, and Tomlinson IPM. Adult leydig cell tumors of the testis caused by germline fumarate hydratase mutations. J Clin Endocrinol Metab 91: 3071-3075, 2006.

21. Chesnelong C, Chaumeil MM, Blough MD, Al-Najjar M, Stechishin OD, Chan JA, Pieper RO, Ronen SM, Weiss S, Luchman HA, and Cairncross JG. Lactate dehydrogenase
A silencing in IDH mutant gliomas. Neuro Oncol 16: 686695, 2014.

22. Chouchani ET, Pell VR, Gaude E, Aksentijević D, Sundier SY, Robb EL, Logan A, Nadtochiy SM, Ord ENJ, Smith AC, Eyassu F, Shirley R, Hu C-H, Dare AJ, James AM, Rogatti S, Hartley RC, Eaton S, Costa ASH, Brookes PS, Davidson SM, Duchen MR, Saeb-Parsy K, Shattock MJ, Robinson AJ, Work LM, Frezza C, Krieg T, and Murphy MP. Ischaemic accumulation of succinate controls reperfusion injury through mitochondrial ROS. Nature 515: 431-435, 2014.

23. Chowdhury R, Yeoh KK, Tian Y-M, Hillringhaus L, Bagg EA, Rose NR, Leung IKH, Li XS, Woon ECY, Yang M, McDonough MA, King ON, Clifton IJ, Klose RJ, Claridge TDW, Ratcliffe PJ, Schofield CJ, and Kawamura A. The oncometabolite 2-hydroxyglutarate inhibits histone lysine demethylases. EMBO Rep 12: 463-469, 2011.

24. Dang L, White DW, Gross S, Bennett BD, Bittinger MA, Driggers EM, Fantin VR, Jang HG, Jin S, Keenan MC, Marks KM, Prins RM, Ward PS, Yen KE, Liau LM, Rabinowitz JD, Cantley LC, Thompson CB, Vander Heiden MG, and Su SM. Cancer-associated IDH1 mutations produce 2-hydroxyglutarate. Nature 462: 739-744, 2009.

25. DeNicola GM, Karreth FA, Humpton TJ, Gopinathan A, Wei C, Frese K, Mangal D, Yu KH, Yeo CJ, Calhoun ES, Scrimieri F, Winter JM, Hruban RH, Iacobuzio-Donahue C, Kern SE, Blair IA, and Tuveson DA. Oncogene-induced Nrf2 transcription promotes ROS detoxification and tumorigenesis. Nature 475: 106-109, 2011.

26. Dik E, Naamati A, Asraf H, Lehming N, and Pines O. Human fumarate hydratase is dual localized by an alternative transcription initiation mechanism. Traffic 17: 720-732, 2016.

27. Domínguez-Andrés J, Novakovic B, Li Y, Scicluna BP, Gresnigt MS, Arts RJW, Oosting M, Moorlag SJCFM, Groh LA, Zwaag J, Koch RM, Ter Horst R, Joosten LAB, Wijmenga C, Michelucci A, van der Poll T, Kox M, Pickkers P, Kumar V, Stunnenberg H, and Netea MG. The itaconate pathway is a central regulatory node linking innate immune tolerance and trained immunity. Cell Metab 29: 211-220.e5, 2019.

28. Du J, Zhou Y, Su X, Yu JJ, Khan S, Jiang H, Kim J, Woo J, Kim JH, Choi BH, He B, Chen W, Zhang S, Cerione RA, Auwerx J, Hao Q, and Lin H. Sirt5 is a NADdependent protein lysine demalonylase and desuccinylase. Science 334: 806-809, 2011.

29. ElAzzouny M, Tom CTMB, Evans CR, Olson LL, Tanga MJ, Gallagher KA, Martin BR, and Burant CF. Dimethyl itaconate is not metabolized into itaconate intracellularly. J Biol Chem 292: 4766-4769, 2017.

30. Flavahan WA, Drier Y, Liau BB, Gillespie SM, Venteicher AS, Stemmer-Rachamimov AO, Suvà ML, and Bernstein BE. Insulator dysfunction and oncogene activation in IDH mutant gliomas. Nature 529: 110-114, 2016.

31. Folger O, Jerby L, Frezza C, Gottlieb E, Ruppin E, and Shlomi T. Predicting selective drug targets in cancer through metabolic networks. Mol Syst Biol 7: 501, 2011.

32. Frezza C, Zheng L, Folger O, Rajagopalan KN, MacKenzie ED, Jerby L, Micaroni M, Chaneton B, Adam J, Hedley A, Kalna G, Tomlinson IPM, Pollard PJ, Watson DG, Deberardinis RJ, Shlomi T, Ruppin E, and Gottlieb E. Haem oxygenase is synthetically lethal with the tumour suppressor fumarate hydratase. Nature 477: 225-228, 2011. 
33. Fu X, Chin RM, Vergnes L, Hwang H, Deng G, Xing Y, Pai MY, Li S, Ta L, Fazlollahi F, Chen C, Prins RM, Teitell MA, Nathanson DA, Lai A, Faull KF, Jiang M, Clarke SG, Cloughesy TF, Graeber TG, Braas D, Christofk HR, Jung ME, Reue K, and Huang J. 2-Hydroxyglutarate Inhibits ATP Synthase and mTOR Signaling. Cell Metab 22: 508-515, 2015.

34. Ghoreschi K, Brück J, Kellerer C, Deng C, Peng H, Rothfuss O, Hussain RZ, Gocke AR, Respa A, Glocova I, Valtcheva N, Alexander E, Feil S, Feil R, Schulze-Osthoff K, Rupec RA, Lovett-Racke AE, Dringen R, Racke MK, and Röcken M. Fumarates improve psoriasis and multiple sclerosis by inducing type II dendritic cells. J Exp Med 208: 2291-2303, 2011.

35. Gimenez-Roqueplo AP, Favier J, Rustin P, Mourad JJ, Plouin PF, Corvol P, Rötig A, and Jeunemaitre X. The R22X mutation of the SDHD gene in hereditary paraganglioma abolishes the enzymatic activity of complex II in the mitochondrial respiratory chain and activates the hypoxia pathway. Am J Hum Genet 69: 1186-1197, 2001.

36. Gottlieb E and Tomlinson IPM. Mitochondrial tumour suppressors: a genetic and biochemical update. Nat Rev Cancer 5: 857-866, 2005.

37. Grassian AR, Parker SJ, Davidson SM, Divakaruni AS, Green CR, Zhang X, Slocum KL, Pu M, Lin F, Vickers C, Joud-Caldwell C, Chung F, Yin H, Handly ED, Straub C, Growney JD, Vander Heiden MG, Murphy AN, Pagliarini $\mathrm{R}$, and Metallo CM. IDH1 mutations alter citric acid cycle metabolism and increase dependence on oxidative mitochondrial metabolism. Cancer Res 74: 3317-3331, 2014.

38. Guzy RD, Sharma B, Bell E, Chandel NS, and Schumacker PT. Loss of the SdhB, but Not the SdhA, subunit of complex II triggers reactive oxygen species-dependent hypoxia-inducible factor activation and tumorigenesis. Mol Cell Biol 28: 718-731, 2008.

39. Hao H-X, Khalimonchuk O, Schraders M, Dephoure N, Bayley J-P, Kunst H, Devilee P, Cremers CWRJ, Schiffman JD, Bentz BG, Gygi SP, Winge DR, Kremer H, and Rutter J. SDH5, a gene required for flavination of succinate dehydrogenase, is mutated in paraganglioma. Science 325: 1139-1142, 2009.

40. Heiden M and DeBerardinis R. Understanding the intersections between metabolism and cancer biology. Cell 168: 657-669, 2017.

41. Hollander AP, Corke KP, Freemont AJ, and Lewis CE. Expression of hypoxia-inducible factor 1alpha by macrophages in the rheumatoid synovium: implications for targeting of therapeutic genes to the inflamed joint. Arthritis Rheum 44: 1540-1544, 2001.

42. Inoue S, Li WY, Tseng A, Beerman I, Elia AJ, Bendall SC, Lemonnier F, Kron KJ, Cescon DW, Hao Z, Lind EF, Takayama N, Planello AC, Shen SY, Shih AH, Larsen DM, Li Q, Snow BE, Wakeham A, Haight J, Gorrini C, Bassi C, Thu KL, Murakami K, Elford AR, Ueda T, Straley K, Yen KE, Melino G, Cimmino L, Aifantis I, Levine RL, De Carvalho DD, Lupien M, Rossi DJ, Nolan GP, Cairns RA, and Mak TW. Mutant IDH1 downregulates ATM and alters DNA repair and sensitivity to DNA damage independent of TET2. Cancer Cell 30: 337-348, 2016.

43. Isaacs JS, Yun JJ, Mole DR, Lee S, Torres-Cabala C, Chung YL, Merino M, Trepel J, Zbar B, Toro J, Ratcliffe PJ, Linehan WM, and Neckers L. HIF overexpression correlates with biallelic loss of fumarate hydratase in renal cancer: novel role of fumarate in regulation of HIF stability. Cancer Cell 8: 143-153, 2005.
44. Ishii T, Yasuda K, Akatsuka A, Hino O, Hartman PS, and Ishii N. A mutation in the SDHC gene of complex II increases oxidative stress, resulting in apoptosis and tumorigenesis. Cancer Res 65: 203-209, 2005.

45. Izquierdo-Garcia JL, Viswanath P, Eriksson P, Cai L, Radoul M, Chaumeil MM, Blough M, Luchman HA, Weiss S, Cairncross JG, Phillips JJ, Pieper RO, and Ronen SM. IDH1 Mutation induces reprogramming of pyruvate metabolism. Cancer Res 75: 2999-3009, 2015.

46. Jha AK, Huang SC-C, Sergushichev A, Lampropoulou V, Ivanova Y, Loginicheva E, Chmielewski K, Stewart KM, Ashall J, Everts B, Pearce EJ, Driggers EM, and Artyomov MN. Network integration of parallel metabolic and transcriptional data reveals metabolic modules that regulate macrophage polarization. Immunity 42: 419-430, 2015.

47. Keiran N, Ceperuelo-Mallafré V, Calvo E, HernándezAlvarez MI, Ejarque M, Núñez-Roa C, Horrillo D, MaymóMasip E, Rodríguez MM, Fradera R, de la Rosa JV, Jorba R, Megia A, Zorzano A, Medina-Gómez G, Serena C, Castrillo A, Vendrell J, and Fernández-Veledo S. SUCNR1 controls an anti-inflammatory program in macrophages to regulate the metabolic response to obesity. Nat Immunol 20: 581-592, 2019.

48. Kelly B and O'Neill LAJ. Metabolic reprogramming in macrophages and dendritic cells in innate immunity. Cell Res 25: 771-784, 2015.

49. Kerrigan JF, Aleck KA, Tarby TJ, Bird CR, and Heidenreich RA. Fumaric aciduria: clinical and imaging features. Ann Neurol 47: 583-588, 2000.

50. Kobayashi EH, Suzuki T, Funayama R, Nagashima T, Hayashi M, Sekine H, Tanaka N, Moriguchi T, Motohashi H, Nakayama K, and Yamamoto M. Nrf2 suppresses macrophage inflammatory response by blocking proinflammatory cytokine transcription. Nat Commun 7: 11624, 2016.

51. Kornberg MD, Bhargava P, Kim PM, Putluri V, Snowman AM, Putluri N, Calabresi PA, and Snyder SH. Dimethyl fumarate targets GAPDH and aerobic glycolysis to modulate immunity. Science 360: 449, 2018.

52. Lampropoulou V, Sergushichev A, Bambouskova M, Nair S, Vincent EE, Loginicheva E, Cervantes-Barragan L, Ma $\mathrm{X}$, Huang SC-C, Griss T, Weinheimer CJ, Khader S, Randolph GJ, Pearce EJ, Jones RG, Diwan A, Diamond MS, and Artyomov MN. Itaconate links inhibition of succinate dehydrogenase with macrophage metabolic remodeling and regulation of inflammation. Cell Metab 24: 158-166, 2016.

53. Laukka T, Mariani CJ, Ihantola T, Cao JZ, Hokkanen J, Kaelin WG, Godley LA, and Koivunen P. Fumarate and succinate regulate expression of hypoxia-inducible genes via TET enzymes. J Biol Chem 291: 4256-4265, 2016.

54. Launonen V, Vierimaa O, Kiuru M, Isola J, Roth S, Pukkala E, Sistonen P, Herva R, and Aaltonen LA. Inherited susceptibility to uterine leiomyomas and renal cell cancer. Proc Natl Acad Sci U S A 98: 3387-3392, 2001.

55. Lee CG, Jenkins NA, Gilbert DJ, Copeland NG, and O'Brien WE. Cloning and analysis of gene regulation of a novel LPSinducible cDNA. Immunogenetics 41: 263-270, 1995.

56. Lehtonen HJ, Kiuru M, Ylisaukko-Oja SK, Salovaara R, Herva R, Koivisto PA, Vierimaa O, Aittomäki K, Pukkala $\mathrm{E}$, Launonen V, and Aaltonen LA. Increased risk of cancer in patients with fumarate hydratase germline mutation. $J$ Med Genet 43: 523-526, 2006.

57. Letouzé E, Martinelli C, Loriot C, Burnichon N, Abermil N, Ottolenghi C, Janin M, Menara M, Nguyen AT, Benit 
P, Buffet A, Marcaillou C, Bertherat J, Amar L, Rustin P, De Reyniès A, Gimenez-Roqueplo A-P, and Favier J. SDH mutations establish a hypermethylator phenotype in paraganglioma. Cancer Cell 23: 739-752, 2013.

58. Li F, He X, Ye D, Lin Y, Yu H, Yao C, Huang L, Zhang J, Wang F, Xu S, Wu X, Liu L, Yang C, Shi J, He X, Liu J, Qu Y, Guo F, Zhao J, Xu W, and Zhao S. NADP+-IDH mutations promote hypersuccinylation that impairs mitochondria respiration and induces apoptosis resistance. $\mathrm{Mol}$ Cell 60: 661-675, 2015.

59. Liao S-T, Han C, Xu D-Q, Fu X-W, Wang J-S, and Kong L-Y. 4-Octyl itaconate inhibits aerobic glycolysis by targeting GAPDH to exert anti-inflammatory effects. Nat Commun 10: 5091, 2019.

60. Libe R, Vescovo L, Burnichon N, Brie J, Jouanno E, Jeunemaitre X, Paris F-, Brière J-J, Libé R, Vescovo L, Rivière $\mathrm{J}$, Tissier $\mathrm{F}$, Jouanno $\mathrm{E}$, Jeunemaitre $\mathrm{X}$, Bénit $\mathrm{P}$, Tzagoloff A, Rustin P, Bertherat J, Favier J, and GimenezRoqueplo A-P. SDHA is a tumor suppressor gene causing paraganglioma. Hum Mol Genet 19: 3011-3020, 2010.

61. Littlewood-Evans A, Sarret S, Apfel V, Loesle P, Dawson J, Zhang J, Muller A, Tigani B, Kneuer R, Patel S, Valeaux S, Gommermann N, Rubic-Schneider T, Junt T, and Carballido JM. GPR91 senses extracellular succinate released from inflammatory macrophages and exacerbates rheumatoid arthritis. J Exp Med 213: 1655-1662, 2016.

62. Liu L, Luc Y, Martinez J, Bi Y, Lian G, Wang T, Milasta S, Wang J, Yang M, Liu G, Green DR, and Wang R. Proinflammatory signal suppresses proliferation and shifts macrophage metabolism from Myc-dependent to HIF1 $\alpha$-dependent. Proc Natl Acad Sci U S A 113: 15641569, 2016.

63. Loriot C, Domingues M, Berger A, Menara M, Ruel M, Morin A, Castro-Vega L-J, Letouzé É, Martinelli C, Bemelmans A-P, Larue L, Gimenez-Roqueplo A-P, and Favier J. Deciphering the molecular basis of invasiveness in Sdhb-deficient cells. Oncotarget 6: 32955-32965, 2015.

64. Losman JA, Looper RE, Koivunen P, Lee S, Schneider RK, McMahon C, Cowley GS, Root DE, Ebert BL, and Kaelin WG. (R)-2-hydroxyglutarate is sufficient to promote leukemogenesis and its effects are reversible. Science 339: 1621-1625, 2013.

65. Lu C, Ward PS, Kapoor GS, Rohle D, Turcan S, AbdelWahab O, Edwards CR, Khanin R, Figueroa ME, Melnick A, Wellen KE, O'Rourke DM, Berger SL, Chan TA, Levine RL, Mellinghoff IK, and Thompson CB. IDH mutation impairs histone demethylation and results in a block to cell differentiation. Nature 483: 474-478, 2012.

66. Lussey-Lepoutre C, Hollinshead KER, Ludwig C, Menara M, Morin A, Castro-Vega L-J, Parker SJ, Janin M, Martinelli C, Ottolenghi C, Metallo C, Gimenez-Roqueplo A-P, Favier J, and Tennant DA. Loss of succinate dehydrogenase activity results in dependency on pyruvate carboxylation for cellular anabolism. Nat Commun 6: 8784, 2015.

67. Macias-Ceja DC, Ortiz-Masiá D, Salvador P, GisbertFerrándiz L, Hernández C, Hausmann M, Rogler G, Esplugues JV, Hinojosa J, Alós R, Navarro F, Cosin-Roger J, Calatayud S, and Barrachina MD. Succinate receptor mediates intestinal inflammation and fibrosis. Mucosal Immunol 12: 178-187, 2019.

68. Marcucci G, Maharry K, Wu Y-Z, Radmacher MD, Mrózek K, Margeson D, Holland KB, Whitman SP, Becker H, Schwind S, Metzeler KH, Powell BL, Carter TH, Kolitz JE, Wetzler M, Carroll AJ, Baer MR, Caligiuri
MA, Larson RA, and Bloomfield CD. IDH1 and IDH2 gene mutations identify novel molecular subsets within de novo cytogenetically normal acute myeloid leukemia: a Cancer and Leukemia Group B study. J Clin Oncol 28: 2348-2355, 2010.

69. Mardis ER, Ding L, Dooling DJ, Larson DE, McLellan MD, Chen K, Koboldt DC, Fulton RS, Delehaunty KD, McGrath SD, Fulton LA, Locke DP, Magrini VJ, Abbott RM, Vickery TL, Reed JS, Robinson JS, Wylie T, Smith SM, Carmichael L, Eldred JM, Harris CC, Walker J, Peck JB, Du F, Dukes AF, Sanderson GE, Brummett AM, Clark E, McMichael JF, Meyer RJ, Schindler JK, Pohl CS, Wallis JW, Shi X, Lin L, Schmidt H, Tang Y, Haipek C, Wiechert ME, Ivy JV, Kalicki J, Elliott G, Ries RE, Payton JE, Westervelt P, Tomasson MH, Watson MA, Baty J, Heath S, Shannon WD, Nagarajan R, Link DC, Walter MJ, Graubert TA, DiPersio JF, Wilson RK, and Ley TJ. Recurring mutations found by sequencing an acute myeloid leukemia genome. N Engl J Med 361: 1058-1066, 2009.

70. McBrayer SK, Mayers JR, DiNatale GJ, Shi DD, Khanal J, Chakraborty AA, Sarosiek KA, Briggs KJ, Robbins AK, Sewastianik T, Shareef SJ, Olenchock BA, Parker SJ, Tateishi K, Spinelli JB, Islam M, Haigis MC, Looper RE, Ligon KL, Bernstein BE, Carrasco RD, Cahill DP, Asara JM, Metallo CM, Yennawar NH, Vander Heiden MG, and Kaelin WG. Transaminase inhibition by 2-hydroxyglutarate impairs glutamate biosynthesis and redox homeostasis in glioma. Cell 175: 101-116.e25, 2018.

71. McCreath KJ, Espada S, Gálvez BG, Benito M, de Molina A, Sepúlveda P, and Cervera AM. Targeted disruption of the SUCNR1 metabolic receptor leads to dichotomous effects on obesity. Diabetes 64: 1154-1167, 2015.

72. Metallo CM, Gameiro PA, Bell EL, Mattaini KR, Yang J, Hiller K, Jewell CM, Johnson ZR, Irvine DJ, Guarente L, Kelleher JK, Vander Heiden MG, Iliopoulos O, and Stephanopoulos G. Reductive glutamine metabolism by IDH1 mediates lipogenesis under hypoxia. Nature 481: 380-384, 2011.

73. Mi RK, Min SK, Ji EO, Yoo RK, Sang YS, Seong IS, Ji YL, Nam JY, and Sug HL. Mutational analysis of IDH1 codon 132 in glioblastomas and other common cancers. Int $J$ Cancer 125: 353-355, 2009.

74. Michelucci A, Cordes T, Ghelfi J, Pailot A, Reiling N, Goldmann O, Binz T, Wegner A, Tallam A, Rausell A, Buttini M, Linster CL, Medina E, Balling R, and Hiller $\mathrm{K}$. Immune-responsive gene 1 protein links metabolism to immunity by catalyzing itaconic acid production. Proc Natl Acad Sci U S A 110: 7820-7825, 2013.

75. Mills EL, Kelly B, Logan A, Costa ASH, Varma M, Bryant CE, Tourlomousis P, Däbritz JHM, Gottlieb E, Latorre I, Corr SC, McManus G, Ryan D, Jacobs HT, Szibor M, Xavier RJ, Braun T, Frezza C, Murphy MP, and O'Neill LA. Succinate dehydrogenase supports metabolic repurposing of mitochondria to drive inflammatory macrophages. Cell 167: 457-470.e13, 2016.

76. Mills EL, Ryan DG, Prag HA, Dikovskaya D, Menon D, Zaslona Z, Jedrychowski MP, Costa ASH, Higgins M, Hams E, Szpyt J, Runtsch MC, King MS, McGouran JF, Fischer R, Kessler BM, McGettrick AF, Hughes MM, Carroll RG, Booty LM, Knatko EV, Meakin PJ, Ashford MLJ, Modis LK, Brunori G, Sévin DC, Fallon PG, Caldwell ST, Kunji ERS, Chouchani ET, Frezza C, Dinkova-Kostova AT, Hartley RC, Murphy MP, and O'Neill LA. Itaconate is an anti-inflammatory metabolite that activates $\mathrm{Nrf} 2$ via alkylation of KEAP1. Nature 556: 113-117, 2018. 
77. Mullen AR, Wheaton WW, Jin ES, Chen PH, Sullivan LB, Cheng T, Yang Y, Linehan WM, Chandel NS, and Deberardinis RJ. Reductive carboxylation supports growth in tumour cells with defective mitochondria. Nature 481: 385-388, 2011.

78. Müller U and Niemann S. Mutations in SDHC cause autosomal dominant paraganglioma, type 3. Nat Genet 26: 268-270, 2000.

79. Murphy MP and O'Neill LAJ. Krebs cycle reimagined: the emerging roles of succinate and itaconate as signal transducers. Cell 174: 780-784, 2018.

80. Niemann S and Muller U. Mutations in SDHC cause autosomal dominant paraganglioma, type 3. Nat Genet 26: 268-270, 2000.

81. O'Neill LAJ, Kishton RJ, and Rathmell J. A guide to immunometabolism for immunologists. Nat Rev Immunol 16: 553-565, 2016.

82. Ozer A and Bruick RK. Non-heme dioxygenases: cellular sensors and regulators jelly rolled into one? Nat Chem Biol 3: 144-153, 2007.

83. Parsons DW, Jones S, Zhang X, Lin JCH, Leary RJ, Angenendt P, Mankoo P, Carter H, Siu IM, Gallia GL, Olivi A, McLendon R, Rasheed BA, Keir S, Nikolskaya T, Nikolsky Y, Busam DA, Tekleab H, Diaz LA, Hartigan J, Smith DR, Strausberg RL, Marie SKN, Shinjo SMO, Yan H, Riggins GJ, Bigner DD, Karchin R, Papadopoulos N, Parmigiani G, Vogelstein B, Velculescu VE, and Kinzler KW. An integrated genomic analysis of human glioblastoma multiforme. Science 321: 1807-1812, 2008.

84. Peruzzotti-Jametti L, Bernstock JD, Vicario N, Costa ASH, Kwok CK, Leonardi T, Booty LM, Bicci I, Balzarotti B, Volpe G, Mallucci G, Manferrari G, Donegà M, Iraci N, Braga A, Hallenbeck JM, Murphy MP, Edenhofer F, Frezza $\mathrm{C}$, and Pluchino S. Macrophage-derived extracellular succinate licenses neural stem cells to suppress chronic neuroinflammation. Cell Stem Cell 22: 355-368.e13, 2018.

85. Peyssonnaux C, Cejudo-Martin P, Doedens A, Zinkernagel AS, Johnson RS, and Nizet V. Cutting edge: essential role of hypoxia inducible factor- $1 \alpha$ in development of lipopolysaccharide-induced sepsis. J Immunol 178: 75167519, 2007.

86. Philip B, Yu DX, Silvis MR, Shin CH, Robinson JP, Robinson GL, Welker AE, Angel SN, Tripp SR, Sonnen JA, VanBrocklin MW, Gibbons RJ, Looper RE, Colman $\mathrm{H}$, and Holmen SL. Mutant idh1 promotes glioma formation in vivo. Cell Rep 23: 1553-1564, 2018.

87. Pollard PJ, Brière JJ, Alam NA, Barwell J, Barclay E, Wortham NC, Hunt T, Mitchell M, Olpin S, Moat SJ, Hargreaves IP, Heales SJ, Chung YL, Griffiths JR, Dalgleish A, McGrath JA, Gleeson MJ, Hodgson SV, Poulsom R, Rustin P, and Tomlinson IPM. Accumulation of Krebs cycle intermediates and over-expression of HIF1alpha in tumours which result from germline $\mathrm{FH}$ and SDH mutations. Hum Mol Genet 14: 2231-2239, 2005.

88. Pollard PJ, Spencer-Dene B, Shukla D, Howarth K, Nye E, El-Bahrawy M, Deheragoda M, Joannou M, McDonald S, Martin A, Igarashi P, Varsani-Brown S, Rosewell I, Poulsom R, Maxwell P, Stamp GW, and Tomlinson IPM. Targeted inactivation of Fh1 causes proliferative renal cyst development and activation of the hypoxia pathway. Cancer Cell 11: 311-319, 2007.

89. Puchalska P, Huang X, Martin SE, Han X, Patti GJ, and Crawford PA. Isotope tracing untargeted metabolomics reveals macrophage polarization-state-specific metabolic coordination across intracellular compartments. iScience 9: 298-313, 2018.

90. Rasola A, Neckers L, and Picard D. Mitochondrial oxidative phosphorylation TRAP(1)ped in tumor cells. Trends Cell Biol 24: 455-463, 2014.

91. Reitman ZJ, Jin G, Karoly ED, Spasojevic I, Yang J, Kinzler KW, He Y, Bigner DD, Vogelstein B, and Yan $\mathrm{H}$. Profiling the effects of isocitrate dehydrogenase 1 and 2 mutations on the cellular metabolome. Proc Natl Acad Sci U S A 108: 3270-3275, 2011.

92. Ricketts C, Woodward ER, Killick P, Morris MR, Astuti D, Latif F, and Maher ER. Germline SDHB mutations and familial renal cell carcinoma. J Natl Cancer Inst 100: 1260-1262, 2008.

93. Rius J, Guma M, Schachtrup C, Akassoglou K, Zinkernagel AS, Nizet V, Johnson RS, Haddad GG, and Karin M. NF-kappaB links innate immunity to the hypoxic response through transcriptional regulation of HIF-1alpha. Nature 453: 807-811, 2008.

94. Rubic T, Lametschwandtner G, Jost S, Hinteregger S, Kund J, Carballido-Perrig N, Schwärzler C, Junt T, Voshol $\mathrm{H}$, Meingassner JG, Mao X, Werner G, Rot A, and Carballido JM. Triggering the succinate receptor GPR91 on dendritic cells enhances immunity. Nat Immunol 9: 12611269, 2008.

95. Ryan DG, Murphy MP, Frezza C, Prag HA, Chouchani ET, O'Neill LA, and Mills EL. Coupling Krebs cycle metabolites to signalling in immunity and cancer. Nat Metab 1: 16-33, 2019.

96. Rzem R, Veiga-da-Cunha M, Noël G, Goffette S, Nassogne M-C, Tabarki B, Schöller C, Marquardt T, Vikkula $M$, and Van Schaftingen E. A gene encoding a putative FAD-dependent L-2-hydroxyglutarate dehydrogenase is mutated in L-2-hydroxyglutaric aciduria. Proc Natl Acad Sci U S A 101: 16849-16854, 2004.

97. Sadagopan N, Li W, Roberds SL, Major T, Preston GM, $\mathrm{Yu}$ Y, and Tones MA. Circulating succinate is elevated in rodent models of hypertension and metabolic disease. Am J Hypertens 20: 1209-1215, 2007.

98. Saito R, Suzuki T, Hiramoto K, Asami S, Naganuma E, Suda H, Iso T, Yamamoto H, Morita M, Furusawa Y, Negishi T, Ichinose $\mathrm{M}$, and Yamamoto $\mathrm{M}$. Characterizations of three major cysteine sensors of Keap1 in stress response. Mol Cell Biol 36: 271-284, 2015.

99. Sass E, Blachinsky E, Karniely S, and Pines O. Mitochondrial and cytosolic isoforms of yeast fumarase are derivatives of a single translation product and have identical amino termini. J Biol Chem 276: 46111-46117, 2001.

100. Schito L and Semenza GL. Hypoxia-inducible factors: master regulators of cancer progression. Trends Cancer 2: 758-770, 2016.

101. Sciacovelli M and Frezza C. Oncometabolites: unconventional triggers of oncogenic signalling cascades. Free Radic Biol Med 100: 175-181, 2016.

102. Sciacovelli M, Gonçalves E, Johnson TI, Zecchini VR, Da Costa ASH, Gaude E, Drubbel AV, Theobald SJ, Abbo SR, Tran MGB, Rajeeve V, Cardaci S, Foster S, Yun H, Cutillas P, Warren A, Gnanapragasam V, Gottlieb E, Franze K, Huntly B, Maher ER, Maxwell PH, SaezRodriguez J, and Frezza C. Fumarate is an epigenetic modifier that elicits epithelial-to-mesenchymal transition. Nature 537: 544-547, 2016.

103. Sciacovelli M, Guzzo G, Morello V, Frezza C, Zheng L, Nannini N, Calabrese F, Laudiero G, Esposito F, Land- 
riscina $\mathrm{M}$, Defilippi $\mathrm{P}$, Bernardi $\mathrm{P}$, and Rasola $\mathrm{A}$. The mitochondrial chaperone TRAP1 promotes neoplastic growth by inhibiting succinate dehydrogenase. Cell Metab 17: 988-999, 2013.

104. Selak MA, Armour SM, MacKenzie ED, Boulahbel H, Watson DG, Mansfield KD, Pan Y, Simon MC, Thompson CB, and Gottlieb E. Succinate links TCA cycle dysfunction to oncogenesis by inhibiting HIF-alpha prolyl hydroxylase. Cancer Cell 7: 77-85, 2005.

105. Serena C, Ceperuelo-Mallafré V, Keiran N, Queipo-Ortuño MI, Bernal R, Gomez-Huelgas R, Urpi-Sarda M, Sabater M, Pérez-Brocal V, Andrés-Lacueva C, Moya A, Tinahones FJ, Fernández-Real JM, Vendrell J, and FernándezVeledo S. Elevated circulating levels of succinate in human obesity are linked to specific gut microbiota. ISME J 12: 1642-1657, 2018.

106. Shen H, Campanello GC, Flicker D, Grabarek Z, Hu J, Luo C, Banerjee R, and Mootha VK. The human knockout gene CLYBL connects itaconate to vitamin B12. Cell 171: 771-782.e11, 2017.

107. Sohrabi Y, Godfrey R, and Findeisen HM. Altered cellular metabolism drives trained immunity. Trends Endocrinol Metab 29: 602-605, 2018.

108. Sourbier C, Ricketts CJ, Matsumoto S, Crooks DR, Liao PJ, Mannes PZ, Yang Y, Wei MH, Srivastava G, Ghosh S, Chen V, Vocke CD, Merino M, Srinivasan R, Krishna MC, Mitchell JB, Pendergast AM, Rouault TA, Neckers L, and Linehan WM. Targeting ABL1-mediated oxidative stress adaptation in fumarate hydratase-deficient cancer. Cancer Cell 26: 840-850, 2014.

109. Struys EA, Salomons GS, Achouri Y, Van Schaftingen E, Grosso S, Craigen WJ, Verhoeven NM, and Jakobs C. Mutations in the d-2-hydroxyglutarate dehydrogenase gene cause d-2-hydroxyglutaric Aciduria. Am J Hum Genet 76: 358-360, 2005.

110. Sulkowski PL, Sundaram RK, Oeck S, Corso CD, Liu Y, Noorbakhsh S, Niger M, Boeke M, Ueno D, Kalathil AN, Bao X, Li J, Shuch B, Bindra RS, and Glazer PM. Krebscycle-deficient hereditary cancer syndromes are defined by defects in homologous-recombination DNA repair. Nat Genet 50: 1086-1092, 2018.

111. Sullivan LB, Gui DY, and Vander Heiden MG. Altered metabolite levels in cancer: implications for tumour biology and cancer therapy. Nat Rev Cancer 16: 680-693, 2016.

112. Sun Y, Bandi M, Lofton T, Smith M, Bristow CA, Carugo A, Rogers N, Leonard P, Chang Q, Mullinax R, Han J, Shi X, Seth S, Meyers BA, Miller M, Miao L, Ma X, Feng N, Giuliani V, Geck Do M, Czako B, Palmer WS, Mseeh F, Asara JM, Jiang Y, Morlacchi P, Zhao S, Peoples M, Tieu TN, Warmoes MO, Lorenzi PL, Muller FL, DePinho RA, Draetta GF, Toniatti C, Jones P, Heffernan TP, and Marszalek JR. Functional genomics reveals synthetic lethality between phosphogluconate dehydrogenase and oxidative phosphorylation. Cell Rep 26: 469-482.e5, 2019.

113. Tannahill GM, Curtis AM, Adamik J, Palsson-McDermott EM, McGettrick AF, Goel G, Frezza C, Bernard NJ, Kelly B, Foley NH, Zheng L, Gardet A, Tong Z, Jany SS, Corr SC, Haneklaus M, Caffrey BE, Pierce K, Walmsley S, Beasley FC, Cummins E, Nizet V, Whyte M, Taylor CT, Lin H, Masters SL, Gottlieb E, Kelly VP, Clish C, Auron PE, Xavier RJ, and O'Neill LAJ. Succinate is an inflammatory signal that induces IL-1 $\beta$ through HIF-1 $\alpha$. Nature 496: 238-242, 2013.

114. Tomlinson IPM, Alam NA, Rowan AJ, Barclay E, Jaeger EEM, Kelsell D, Leigh I, Gorman P, Lamlum H, Rahman
S, Roylance RR, Olpin S, Bevan S, Barker K, Hearle N, Houlston RS, Kiuru M, Lehtonen R, Karhu A, Vilkki S, Laiho P, Eklund C, Vierimaa O, Aittomäki K, Hietala M, Sistonen P, Paetau A, Salovaara R, Herva R, Launonen V, and Aaltonen LA; the Multiple Leiomyoma Consortium. Germline mutations in $\mathrm{FH}$ predispose to dominantly inherited uterine fibroids, skin leiomyomata and papillary renal cell cancer. Nat Genet 30: 406-410, 2002.

115. Tommasini-Ghelfi S, Murnan K, Kouri FM, Mahajan AS, May JL, and Stegh AH. Cancer-associated mutation and beyond: the emerging biology of isocitrate dehydrogenases in human disease. Sci Adv 5: eaaw4543, 2019.

116. Tong WH, Sourbier C, Kovtunovych G, Jeong SY, Vira M, Ghosh M, Romero VV, Sougrat R, Vaulont S, Viollet B, Kim YS, Lee S, Trepel J, Srinivasan R, Bratslavsky G, Yang Y, Linehan WM, and Rouault TA. The glycolytic shift in fumarate-hydratase-deficient kidney cancer lowers AMPK levels, increases anabolic propensities and lowers cellular iron levels. Cancer Cell 20: 315-327, 2011.

117. Vanharanta S, Buchta M, McWhinney SR, Virta SK, Peçzkowska M, Morrison CD, Lehtonen R, Januszewicz A, Järvinen H, Juhola M, Mecklin J-P, Pukkala E, Herva R, Kiuru M, Nupponen NN, Aaltonen LA, Neumann HPH, and Eng C. Early-onset renal cell carcinoma as a novel extraparaganglial component of SDHB-associated heritable paraganglioma. Am J Hum Genet 74: 153-159, 2004.

118. Van Vranken JG, Na U, Winge DR, and Rutter J. Proteinmediated assembly of succinate dehydrogenase and its cofactors. Crit Rev Biochem Mol Biol 50: 168-180, 2015.

119. Wang F, Wang K, Xu W, Zhao S, Ye D, Wang Y, Xu Y, Zhou L, Chu Y, Zhang C, Qin X, Yang P, and Yu H. SIRT5 desuccinylates and activates pyruvate kinase M2 to block macrophage IL- $1 \beta$ production and to prevent DSS-induced colitis in mice. Cell Rep 19: 2331-2344, 2017.

120. Wang $\mathrm{P}, \mathrm{Wu}$ J, Ma S, Zhang L, Yao J, Hoadley KA, Wilkerson MD, Perou CM, Guan KL, Ye D, and Xiong Y. Oncometabolite D-2-hydroxyglutarate inhibits ALKBH DNA repair enzymes and sensitizes IDH mutant cells to alkylating agents. Cell Rep 13: 2353-2361, 2015.

121. Ward PS, Patel J, Wise DR, Abdel-Wahab O, Bennett BD, Coller HA, Cross JR, Fantin VR, Hedvat C V, Perl AE, Rabinowitz JD, Carroll M, Su SM, Sharp KA, Levine RL, and Thompson CB. The common feature of leukemiaassociated IDH1 and IDH2 mutations is a neomorphic enzyme activity converting alpha-ketoglutarate to 2hydroxyglutarate. Cancer Cell 17: 225-234, 2010.

122. Weiss JM, Davies LC, Karwan M, Ileva L, Ozaki MK, Cheng RYS, Ridnour LA, Annunziata CM, Wink DA, and McVicar DW. Itaconic acid mediates crosstalk between macrophage metabolism and peritoneal tumors. J Clin Invest 128: 3794-3805, 2018.

123. Xiao M, Yang H, Xu W, Ma S, Lin H, Zhu H, Liu L, Liu Y, Yang C, Xu Y, Zhao S, Ye D, Xiong Y, and Guan K-L. Inhibition of $\alpha$-KG-dependent histone and DNA demethylases by fumarate and succinate that are accumulated in mutations of $\mathrm{FH}$ and SDH tumor suppressors. Genes Dev 26: 1326-1338, 2012.

124. Xu T, Stewart KM, Wang X, Liu K, Xie M, Ryu JK, Li K, Ma T, Wang H, Ni L, Zhu S, Cao N, Zhu D, Zhang Y, Akassoglou K, Dong C, Driggers EM, and Ding S. Metabolic control of TH17 and induced Treg cell balance by an epigenetic mechanism. Nature 548: 228-233, 2017.

125. Xu W, Yang H, Liu Y, Yang Y, Wang P, Kim SH, Ito S, Yang C, Wang P, Xiao MT, Liu LX, Jiang WQ, Liu J, Zhang 
JY, Wang B, Frye S, Zhang Y, Xu YH, Lei QY, Guan KL, Zhao SM, Xiong Y. Oncometabolite 2-hydroxyglutarate is a competitive inhibitor of $\alpha$-ketoglutarate-dependent dioxygenases. Cancer Cell 19: 17-30, 2011.

126. Yan H, Parsons DW, Jin G, McLendon R, Rasheed BA, Yuan W, Kos I, Batinic-Haberle I, Jones S, Riggins GJ, Friedman H, Friedman A, Reardon D, Herndon J, Kinzler KW, Velculescu VE, Vogelstein B, and Bigner DD. IDH1 and IDH2 mutations in gliomas. N Engl J Med 360: 765-773, 2009.

127. Ye D, Guan K-L, and Xiong Y. Metabolism, activity, and targeting of D- and L-2-hydroxyglutarates. Trends Cancer 4: 151-165, 2018.

128. Yogev O, Naamati A, and Pines O. Fumarase: a paradigm of dual targeting and dual localized functions. FEBS $J$ 278: 4230-4242, 2011.

129. Zhao S, Lin Y, Xu W, Jiang W, Zha Z, Wang P, Yu W, Li Z, Gong L, Peng Y, Ding J, Lei Q, Guan K-L, and Xiong Y. Glioma-derived mutations in IDH1 dominantly inhibit IDH1 catalytic activity and induce HIF-1alpha. Science 324: 261-265, 2009.

130. Zheng L, Cardaci S, Jerby L, Mackenzie ED, Sciacovelli M, Johnson TI, Gaude E, King A, Leach JDG, EdradaEbel R, Hedley A, Morrice NA, Kalna G, Blyth K, Ruppin E, Frezza C, and Gottlieb E. Fumarate induces redoxdependent senescence by modifying glutathione metabolism. Nat Commun 6: 6001, 2015.

131. Zheng L, MacKenzie ED, Karim SA, Hedley A, Blyth K, Kalna G, Watson DG, Szlosarek P, Frezza C, and Gottlieb E. Reversed argininosuccinate lyase activity in fumarate hydratase-deficient cancer cells. Cancer Metab 1: 12, 2013.

Address correspondence to:

Dr. Simone Cardaci

Cancer Metabolism Unit

Division of Genetics and Cell Biology IRCCS San Raffaele Scientific Institute Milan 20132

Italy

E-mail: cardaci.simone@hsr.it

Date of first submission to ARS Central, December 9, 2019; date of acceptance, December 13, 2019.

\section{Abbreviations Used}

2-HG $=$ 2-hydroxyglutarate

4-OI $=4$-octyl itaconate

$\alpha-\mathrm{KG}=\alpha$-ketoglutarate

$\alpha$ KGDDs $=\alpha$-KG-dependent dioxygenases

ABL-1 = Abelson murine leukemia viral oncogene homolog 1

AcCoA $=$ acetyl-coenzyme A

ACOD1 $=$ aconitate decarboxylase 1

AMPK $=$ adenosine monophosphate-activated protein kinase

AOAA $=$ aminooxyacetic acid

$\mathrm{ARE}=$ antioxidant response elements

$\mathrm{ASL}=$ argininosuccinate lyase

ATF3 = activating transcription factor 3

ATMs $=$ adipose-tissue-resident macrophages
BCAAs $=$ branched-chain amino acids

BCKAs $=$ branched-chain $\alpha$-ketoacids

$\mathrm{BMDMs}=$ bone marrow-derived macrophages

$\mathrm{CS}=$ citrate synthase

$\mathrm{CTCF}=$ CCCTC-binding factor

D2-HGA = D-2-hydroxyglutaric aciduria

$\mathrm{DCs}=$ dendritic cells

$\mathrm{DI}=$ dimethyl itaconate

$\mathrm{DMF}=$ dimethyl fumarate

$\mathrm{DMM}=$ dimethyl malonate

$\mathrm{EAE}=$ experimental autoimmune encephalomyelitis

$\mathrm{ETC}=$ mitochondrial electron transport chain

$\mathrm{FADH}_{2}=$ flavin adenine dinucleotide (hydroquinone form)

$\mathrm{FH}=$ fumarate hydratase

FOXP3 $=$ forkhead box P3

$\mathrm{GABA}=\gamma$-aminobutyric acid

GAPDH $=$ glyceraldehyde 3-phosphate dehydrogenase

GLUT1 = glucose transporter 1

$\mathrm{GSH}=$ glutathione

$\mathrm{HCC}=$ hepatocellular carcinoma

HIF- $1 \alpha=$ hypoxia-inducible factor- $1 \alpha$

HLRCC $=$ hereditary leiomyomatosis and renal cell cancer syndrome

Hmox $1=$ heme oxygenase 1

$\mathrm{HRE}=$ hypoxia response elements

$\mathrm{IDH}=$ isocitrate dehydrogenase

IL- $1 \beta=$ interleukin- $1 \beta$

IL- $6=$ interleukin 6

$\mathrm{IR}=$ ischemia-reperfusion

IRG1 = immunoresponsive gene 1

$\mathrm{I} \kappa \mathrm{B} \zeta=$ inhibitor of kappa $\mathrm{B}-\zeta$ transcription

$\mathrm{KDMs}=$ histone lysine demethylases

KEAP1 $=$ Kelch-like ECH-associated protein 1

L2-HGA = L-2-hydroxyglutaric

LPS $=$ lipopolysaccharide

$\mathrm{MS}=$ multiple sclerosis

$\mathrm{NADH}=$ nicotinamide adenine dinucleotide (reduced form)

$\mathrm{NSCs}=$ neural stem cells

$\mathrm{NRF} 2=$ nuclear factor erythroid 2-like 2

OXPHOS $=$ oxidative phosphorylation

$\mathrm{PGD}=$ phosphogluconate dehydrogenase

$\mathrm{PGG}=$ paraganglioma

PHDs $=$ prolyl-hydroxylases

$\mathrm{PHEO}=$ pheochromocytoma

$\mathrm{PKM} 2=$ pyruvate kinase $\mathrm{M} 2$

$\mathrm{PTM}=$ post-translational modification

$\mathrm{RET}=$ reverse electron transfer

ROS $=$ reactive oxygen species

$\mathrm{SDH}=$ succinate dehydrogenase

SNAI2 $=$ snail homolog 2

SUCNR1 $=$ succinate receptor 1

$\mathrm{TCA}=$ tricarboxylic acid

TETs $=$ ten-eleven translocation proteins

$\mathrm{T}_{\mathrm{H}} 17=\mathrm{T}$ helper 17

TLR4 $=$ Toll-like receptor 4

TNF- $\alpha=$ tumor necrosis factor- $\alpha$

TRAP1 $=$ tumor necrosis factor-associated protein 1

Treg $=$ regulatory $\mathrm{T}$

ZEB1 = zinc-finger E-box binding homeobox 1

ZEB2 = zinc-finger E-box binding homeobox 2 